\title{
Characterization of process-oriented hydrologic model behavior with temporal sensitivity analysis for flash floods in Mediterranean catchments
}

\author{
P. A. Garambois ${ }^{1,2}$, H. Roux ${ }^{1,2}$, K. Larnier ${ }^{1,2}$, W. Castaings ${ }^{3}$, and D. Dartus ${ }^{1,2}$ \\ ${ }^{1}$ Université de Toulouse, INPT, UPS, IMFT (Institut de Mécanique des Fluides de Toulouse), Allée Camille Soula, \\ 31400 Toulouse, France \\ ${ }^{2}$ CNRS, IMFT, 31400 Toulouse, France \\ ${ }^{3}$ EDYTEM, Université de Savoie, Le Bourget du Lac cedex, France \\ Correspondence to: P. A. Garambois (pgarambo@imft.fr)
}

Received: 4 December 2012 - Published in Hydrol. Earth Syst. Sci. Discuss.: 28 January 2013

Revised: 21 May 2013 - Accepted: 21 May 2013 - Published: 27 June 2013

\begin{abstract}
This paper presents a detailed analysis of 10 flash flood events in the Mediterranean region using the distributed hydrological model MARINE. Characterizing catchment response during flash flood events may provide new and valuable insight into the dynamics involved for extreme catchment response and their dependency on physiographic properties and flood severity. The main objective of this study is to analyze flash-flood-dedicated hydrologic model sensitivity with a new approach in hydrology, allowing model outputs variance decomposition for temporal patterns of parameter sensitivity analysis. Such approaches enable ranking of uncertainty sources for nonlinear and nonmonotonic mappings with a low computational cost. Hydrologic model and sensitivity analysis are used as learning tools on a large flash flood dataset. With Nash performances above 0.73 on average for this extended set of 10 validation events, the five sensitive parameters of MARINE process-oriented distributed model are analyzed. This contribution shows that soil depth explains more than $80 \%$ of model output variance when most hydrographs are peaking. Moreover, the lateral subsurface transfer is responsible for $80 \%$ of model variance for some catchment-flood events' hydrographs during slow-declining limbs. The unexplained variance of model output representing interactions between parameters reveals to be very low during modeled flood peaks and informs that model-parsimonious parameterization is appropriate to tackle the problem of flash floods. Interactions observed after model initialization or rainfall intensity peaks incite to
\end{abstract}

improve water partition representation between flow components and initialization itself. This paper gives a practical framework for application of this method to other models, landscapes and climatic conditions, potentially helping to improve processes understanding and representation.

\section{Problem framework}

\subsection{Flash flood modeling complexity}

The Mediterranean climatic zone is prone to heavy rainfall events especially during the fall season. Either quasistationary mesoscale convective systems, which can last several hours, or frontal disturbances blocked by the mountains can produce high precipitation totals (Nuissier et al., 2008) that trigger severe flash floods. The high variability of precipitations (Moussa et al., 2007) along with topography influence and spatial distribution of soil and land use properties makes hydrological processes largely variable both in time and space (Pilgrim et al., 1988). Flash floods are extreme catchment responses with high peak discharge often produced by severe localized thunderstorms. They are one of the most destructive hazards in the Mediterranean region and have caused casualties and billions of euros of damages in France over the last two decades (Gaume et al., 2009).

These events often reveal aspects of hydrological behavior that either were unexpected on the basis of weaker responses or highlight anticipated but previously unobserved 
behavior (Delrieu et al., 2005). Characterizing the response of a catchment during flash flood events thus may provide new and valuable insight into processes for extreme flood response and their dependency on catchment properties and flood severity (Borga et al., 2008).

In the literature, several approaches are proposed for flash flood events modeling and/or prediction, each with its specificities depending on perception and parameterization of the dominant hydrological processes (Moussa et al., 2007; Saulnier and le Lay, 2009; Braud et al., 2010; Roux et al., 2011) among others for the Mediterranean region. These models often take advantage of available data in order to assign spatially distributed forcing as well as distributed catchment parameters. However, increasing model complexity can lead to overparameterization and equifinality problems because of high dimensionality and multi-modal response surface. As a result, parameter values might not be identifiable in the calibration process (Beven, 1989). Sieber and Uhlenbrook (2005) have highlighted that sensitivity analysis (SA) can not only identify the most important parameters but also contribute to understanding and improving the structure of hydrologic model.

\subsection{Understanding uncertainty with sensitivity analysis}

Sensitivity analysis (SA) assesses the impact of model parameters on the output, and is therefore a convenient tool to investigate model behavior and especially the importance of particular parameterizations within the model. SA has become a popular tool in catchment modeling to explore high dimensional parameter spaces, assess parameter identifiability, and understand sources of uncertainty (Hornberger and Spear, 1981; Freer et al., 1996; Wagener et al., 2001; Hall et al., 2005; van Griensven et al., 2006; Tang et al., 2007). Some studies highlight the usefulness of sensitivity analysis for the improvement of hydrological models (Andréassian et al., 2001; Oudin et al., 2006; Castaings et al., 2007; Ratto et al., 2007b; Tang et al., 2007; Pushpalatha et al., 2011). Other studies used SA to better understand model behavior with respect to inputs such as precipitation (Xu et al., 2006; Meselhe et al., 2009).

With the current shift toward model complexification and/or real-time hydrometeorological forecasts, of prior importance is the understanding of uncertainty and its sources. In catchment modeling it can be achieved with various methods, of which formal Bayesian methods (Kuczera and Parent, 1998) and the GLUE method (Beven and Binley, 1992) are the most popular, as well as recursive application of RSA for dynamic identifiability analysis (Wagener et al., 2003) or Bayesian total error analysis (BATEA) method (Kavetski et al., 2006) for comprehensive calibration and uncertainty estimation. According to Saltelli et al. (2004) sensitivity analysis is the study of how uncertainty in the output of a model can be apportioned to different sources of uncertainty in the model input. Sensitivity analysis is recognized as a helpful parameter-space screening tool to identify key parameters controlling the performances. It can help in reducing problem dimensionality with factor fixing (FF) for noninfluential parameters, and factor prioritization (FP) for those controlling the most model output uncertainty (Saltelli et al., 2000). Besides the selection of the appropriate method for analyzing parameter sensitivity depends strongly on the goal of the sensitivity analysis (Saltelli et al., 2006). Of particular interest is the analysis of the dependence of the model output variance to simultaneously modified parameters; this can be achieved with methods based on variance decomposition (Efron and Stein, 1981; Sobol, 1993). The application of three sensitivity analysis methods including Sobol's method by Massmann and Holzmann (2012) shows that the two most important parameters of their conceptual continuous rainfallrunoff model are correctly identified as being sensitive by all methods.

\subsection{Variance-based methods and temporal sensitivity analysis}

Variance-based methods result in reliable estimates of sensitivities even for nonlinear and nonmonotonic models, as was often demonstrated using examples where analytical solutions can be calculated (Saltelli and Bolado, 1998). The price to be paid in order to relax all assumptions on model behavior is that the required number of model runs is relatively high (> 1000) for most approaches. Some variants of this method, in terms of partial variances calculation, are Sobol's method (Sobol, 1990, 2001) and the extended Fourier amplitude sensitivity test ((E)FAST) (Cukier et al., 1973; Saltelli and Bolado, 1998; Fang et al., 2003; Reusser et al., 2011).

Variance-based sensitivity analysis methods aim to quantify the amount of variance that each parameter contributes to the unconditional variance of the model output. These amounts are characterized by first order or interaction effects expressed as sensitivity indices ( $S_{i}$ 's). Despite its high computational demands contributions (Saltelli, 2002) and trying to make it more effective, the powerful Sobol SA technique, for example, has recently become more popular in environmental modeling (Pappenberger et al., 2007, 2008; Van Werkhoven et al., 2008; Jing, 2011; Li et al., 2012).

Tang et al. (2007) compared state of the art in sensitivity analysis including Sobol's method and found it to be the most effective in estimating first-order parametric sensitivities and overall influence including interaction effects. Tang et al. (2007) make a step-wise analysis of a conceptual gridbase-distributed rainfall-runoff model (HL-RDHM). Their sensitivity analysis reveals the impact of rainfall distribution on spatial sensitivities and input variables mostly controlling HL-RDHM's behavior. The use of Sobol indices for sensitivity analysis purposes is investigated by Nossent et al. (2011) in the case of a SWAT model. They conclude that in general the Sobol sensitivity analysis can be successfully applied for factor fixing and factor prioritization with respect to the input 
parameters of a SWAT model, even with a limited number of model evaluations. The analysis also supports the identification of model processes, parameter values and parameter interaction effects. Some of the recent studies applying SA to rainfall-runoff, flood inundation, and water quality models are listed by Reusser et al. (2011); 8 out of the 18 studies use variance-based methods. In seven studies, on the order of 10000 model runs were computed to calculate sensitivities, which is impossible for computationally expensive models. As highlighted by Reusser et al. (2011), analyzing temporal dynamics of parameter sensitivity (TEDPAS) of model output variables, such as discharge, we can quantify which model components dominate the simulation response. Their analysis reveals that temporal dynamics of model parameter sensitivity can be a powerful tool for hydrological model analysis, especially to identify parameter interaction as well as the dominant hydrological response modes. Reusser and Zehe (2011) with TEDPAS (temporal dynamics of parameter sensitivity) and TIGER (time series of grouped error) methods investigate parameter uncertainty for periods of poor model efficiencies. With modeling and temporal sensitivity analysis used as learning tools, WaSIM-ETH complex gridbased model hypotheses are shown to be insufficient to describe Weisseritz headwater catchment behavior and future developments seem required.

\subsection{Scope of the paper}

The core idea of this paper is to approach hydrologic model sensitivity with temporal sensitivity analysis, here in the case of quick and strong catchment flash flood responses. The originality lies in TEDPAS analysis calculated from variance-based decomposition that may reveal sensitivity peaks and thus flow dynamics at key instants. This kind of analysis is new for hydrologic models especially for eventprocess-oriented distributed models. Using TEDPAS as a diagnostic tool joins the idea of dynamic identifiability introduced by Wagener et al. (2003). But these two methods serve a different purpose since it is a necessary but insufficient condition that parameters must be sensitive in order to be identifiable whereas sensitive parameters may not be identifiable.

In this contribution, a temporal sensitivity analysis of the process-oriented spatially distributed MARINE model dedicated to flash floods is carried out. Based on the understanding of Mediterranean catchments hydrological processes the hydrological rainfall-runoff model MARINE (Modélisation et Anticipation du Ruissellement et des Inondations pour des évèNements Extrêmes) aims at (i) exploiting the potential of distributed models (ii) using physically meaningful parameters, while (iii) maintaining a simple and parsimonious parameterization (Roux et al., 2011). Given a validated model structure for flash floods in the French Mediterranean region, the question of sensitivity is approached in a probabilistic framework. One parameter set for each of the six catchments is tested on validations events for which the analysis of TED-
PAS is performed. The procedure is implemented for contrasted hydrometeorological events in the Cévennes and the Pyrenean region (France) with the view to bring understanding in model behavior for contrasted catchments and flash flood events on steep terrains and complex geo-pedological formations.

The paper is organized as follows. Section 2 describes variance decomposition method and sensitivity indices calculation. MARINE model and the six Mediterranean catchments of interest are presented in Sect. 3. Catchment parameter sets and their efficiencies on 10 validation events are calculated and temporal sensitivity analysis hypotheses are tested in Sect. 4. Then TEDPAS on these validation events are examined in Sect. 5. After a conclusion on the results, processes, variables and parameters that require further description or observations are emphasized and the possibility of applying this method to improve the understanding of the major processes involved in flood events is discussed.

\section{Background on model analysis with variance decomposition methods}

Thoughtful descriptions of sensitivity analysis methods can be found in Saltelli et al. (2000). Variance-based methods are part of the practices Saltelli and Annoni (2010) recommended as an alternative to OAT analysis (one at a time method: local analysis evaluating separately the effect of each individual parameter). Variance-based methods are based on a decomposition of the model output variance.

Let $\Omega_{k} \in \Re^{k}$ denote the set of all possible values that the model parameters can assume. Let $\underline{X} \in \Omega_{k}$ be a possible value of the $k$ model parameters normalized by their variation range. We denote by $Y=g(\underline{X})=g\left(X_{1}, \ldots, X_{k}\right)$ the relationship that links the model inputs to the model output. The parameters $\underline{X}$ have a domain of validity linked to the uncertainty about their precise value.

Assuming that $g$ is a square integrable function over $\Omega_{k}=$ $\left\{X \mid 0 \leq X_{i} \leq 1 ; i=1, \ldots, k\right\}$, it can be decomposed using an expansion with summand $g_{i \ldots p}\left(X_{1}, \ldots, X_{p}\right)$ of increasing dimensionality $p<k$ :

$$
\begin{aligned}
Y & =g(\underline{X})=g_{0}+\sum_{i=1}^{k} g_{i}\left(X_{i}\right)+\sum_{i=1}^{k} \sum_{i>j} g_{i j}\left(X_{i}, X_{j}\right) \\
& +\ldots+g_{1,2, \ldots, k}\left(X_{1}, X_{2}, \ldots, X_{k}\right) .
\end{aligned}
$$

Sobol (1993) proved that this HDMR decomposition (highdimension model representation) was unique if each term in the expansion has zero mean, then all the terms of the decomposition are orthogonal in pairs:

$\int_{\Omega_{k}} g_{i_{1}, \ldots, i_{\mathrm{p}}} g_{i_{1}, \ldots, i_{s}} \mathrm{~d} \underline{X}=0$. 
The total unconditional variance of model output can be defined as

$$
V(Y)=\int_{\Omega_{k}} g^{2}(\underline{X}) \mathrm{d} \underline{X}-g_{0}^{2} .
$$

The partial variances which are the components of the total variance decomposition are computed from each term in Eq. (1) as

$$
V_{i, \ldots, p}=\int_{0}^{1} \int_{0}^{1} g_{i_{1}, \ldots, i_{p}}^{2}\left(X_{i_{1}}, \ldots, X_{i_{p}}\right) \mathrm{d} X_{i_{1}}, \ldots, \mathrm{d} X_{i_{p}} .
$$

The relation (3) expressed with Eqs. (1) and (4) leads to the so-called functional ANOVA decomposition:

$$
V(Y)=\sum_{i} V_{i}+\sum_{i} \sum_{j>i} V_{i j}+\ldots+V_{1,2, \ldots, k},
$$

where $V(Y)$ is the total variance, $V_{i}$ is the variance caused by parameter $X_{i}$ (first-order variance), $V_{i j}$ is the covariance caused by $X_{i}$ and $X_{j}$ (second-order variance), and higher order terms show the variance contribution from multiple parameters. The two factors $X_{i}$ and $X_{j}$ are said to interact when their effect on $Y$ cannot be expressed as the sum of their single effects $V_{i}$ and $V_{j}$. Interactions may imply, for instance, that extreme values of the model output are uniquely associated with particular combinations of model inputs in a way that is not described by first-order effects $S_{i}$.

From this relation (5), sensitivity indices can be defined in order to assess the sensitivity of $Y$ to $\underline{X}$ when $\underline{X}$ is uncertain. The first-order effect representing the average output variance reduction that can be achieved when $X_{i}$ is fixed is defined by

$S_{i}=\frac{V_{i}}{V}=\frac{V(Y)-E_{X_{i}}\left[V\left(Y \mid X_{i}\right)\right]}{V(Y)}=\frac{V_{X_{i}}\left[E\left(Y \mid X_{i}\right)\right]}{V(Y)}$.

The partial variance $V_{i}$ in Eq. (6) is given by the variance of the conditional expectation $V_{i}=V_{X_{i}}\left[E\left(Y \mid X_{i}\right)\right]$ and is also called the main effect of $X_{i}$ on $Y$. The impact on the model output variance of the interactions between parameters $X_{i}$ and $X_{j}$ is given by $S_{i j}=V_{i j} / V$ and it can be generalized in interactions effects up to order $k$ by replacing the index $i$ by the corresponding set of input factors.

The estimation of partial variances could be very expensive with brute-force methods, but a shortcut was proposed by Sobol to reduce the calculation of the double-loop integrals of Eq. (4). Efficient methods such as extended FAST from Saltelli (1999) or improved Sobol from Saltelli (2002) were proposed in order to estimate both $S_{i}$ and $S_{T i}$ for all inputs factors for a computational cost of $N(k+2)$. However, alternatives techniques were introduced recently, allowing the estimation of $S_{i}^{\prime} s$ and low interaction effects (up to order 3 ) for a computational cost independent from $k$ (i.e., equal to
$N$ the sample size) (RBD-FAST from Tarantola et al., 2006; Mara, 2009; Storlie and Helton, 2007; Oakley and O'Hagan, 2004; Sudret, 2008; Crestaux et al., 2009).

The method used in this paper is the state-dependent parameter (SDP) metamodeling method (Ratto et al., 2007a) which is based on recursive filtering and smoothing estimation to build an approximation of the computational model. Ideas and tools from signal processing and time series analysis are used to estimate the terms in the ANOVA-HDMR decomposition using a special recursive fixed-interval smoothing algorithm that estimates the parameters in an SDP formulation of the input-output mapping (Ratto et al., 2007a). It is a very efficient method that does not require any specific rule for sampling inputs, and provides fastly accurate and unbiaised results for both sensitive and insensitive inputs according to (Gatelli et al., 2009). Ratto et al. (2007a) show that even for a large number of parameters the SDP method allows a good estimation of variance-based sensitivity indices with a mild computational cost for models with up to 20 input factors. In the following we use the routine SS-ANOVA (available at http://sensitivity-analysis. jrc.ec.europa.eu/software/index.htm). The recursive filtering and smoothing procedure provides standard errors of the estimated state-dependant parameters and hence the relative significance of estimated HDMR terms and sensitivity indices.

\section{Model and site description}

\subsection{MARINE flash flood model}

The modeling approach is the distributed model MARINE for flash flood forecasting (Roux et al., 2011) with a subsurface transfer module. The predominant factor determining the formation of runoff is represented by the topography: slope and downhill directions. MARINE runs on a fixed time step and is structured into three main modules (Fig. 1). The first module allows separating the precipitation into surface runoff and infiltration using the Green and Ampt model; the second module represents subsurface downhill flow with an approximation of the Darcy's law and the standard TOPMODEL transmissivity profile (Beven and Kirkby, 1979) and the third one the overland flow (over hillslopes and in the drainage network): the transfer function component allows routing the rainfall excess to the catchment outlet using the kinematic wave approximation. Both infiltration excess and saturation excess are represented within MARINE. The spatial discretization of the catchment is performed using the digital elevation model grid resolution, a regular grid of squared cells. Evapotranspiration is not represented since the model purpose was to simulate individual flood events during which such process is negligible. Cell soil moisture deficit is initialized from a continuously distributed water balance model output briefly described later. For a complete 


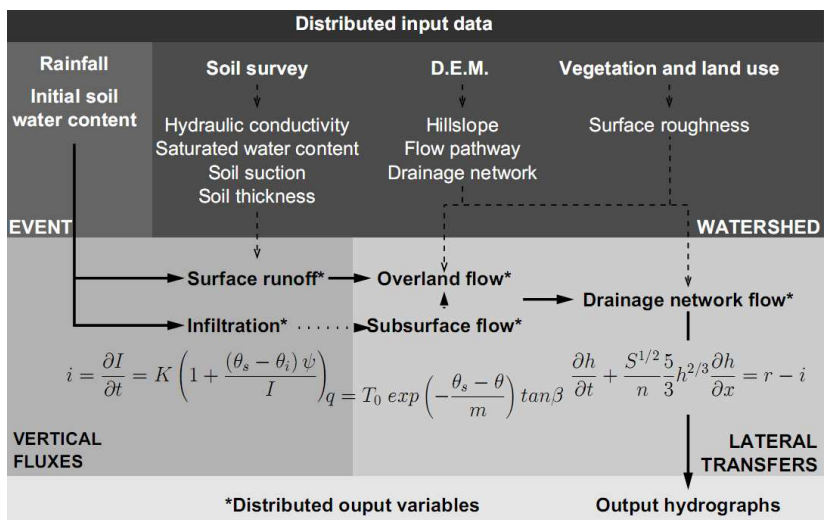

Fig. 1. MARINE model structure, parameters and variables. Green and Ampt infiltration equation: infiltration rate $i\left(\mathrm{~m} \mathrm{~s}^{-1}\right)$, cumulative infiltration $I(\mathrm{~mm})$, saturated hydraulic conductivity $K\left(\mathrm{~m} \mathrm{~s}^{-1}\right)$, soil suction at wetting front $\psi(\mathrm{m})$, saturated and initial water contents are respectively $\theta_{\mathrm{s}}$ and $\theta_{\mathrm{i}}\left(\mathrm{m}^{3} \mathrm{~m}^{-3}\right)$. Subsurface flow: local transmissivity of fully saturated soil $T_{0}\left(\mathrm{~m}^{2} \mathrm{~s}^{-1}\right)$, saturated and local water contents are $\theta_{\mathrm{S}}$ and $\theta\left(\mathrm{m}^{3} \mathrm{~m}^{-3}\right)$, transmissivity decay parameter is $\mathrm{m}(-)$, local slope angle $\beta(\mathrm{rad})$. Kinematic wave: water depth $h(\mathrm{~m})$, time $t(\mathrm{~s})$, overland flow velocity $u\left(\mathrm{~m} \mathrm{~s}^{-1}\right)$, space variable $x(\mathrm{~m})$, rainfall rate $r\left(\mathrm{~m} \mathrm{~s}^{-1}\right)$, infiltration rate $i\left(\mathrm{~m} \mathrm{~s}^{-1}\right)$, bed slope $S\left(\mathrm{~m} \mathrm{~m}^{-1}\right)$, Manning roughness coefficient $n\left(\mathrm{~m}^{-1 / 3} \mathrm{~s}^{-1}\right)$.

description of the MARINE model the reader can refer to Roux et al. (2011).

\subsection{Study zone}

The proximity of the Mediterranean Sea and the steep surrounding orography can promote low-level flow lifting in an unstable atmosphere, as for the Alps and Pyrenees (Davolio et al., 2009; Tarolli et al., 2012). The highest flooding risk is in autumn with wet soils and maximum rainfall rates. Summers are hot and dry; however summer storms also represent a nonnegligible flooding risk. The density of both hydrometeorological radar and hourly rain gauge coverage offers interesting possibilities for flood-triggering rainfall monitoring and quantitative precipitation estimation (Fig. 2). Thus the French Mediterranean region rather frequently affected by intense rainfalls represents an interesting area for flash flood study in a regional manner (Garambois et al., 2012b) with contrasted catchment properties, rainfall distributions and hydrological response characteristics (Garambois et al., 2012a).

From the Pyrenean foothills and the Corbières Mountains in the south to the Cévennes foothills and the Ardèche region, six flood-prone catchments with areas ranging from 144 to $619 \mathrm{~km}^{2}$ and contrasted physiographic properties are selected (Table 1). They present a highly marked topography with narrow valleys and steep hillslopes (Fig. 2). A DEM data file of the study site with a grid scale of $25 \mathrm{~m}$ was available from the National Geographic Institute (BD TOPO ${ }^{\circledR \odot}$ IGN - Paris -

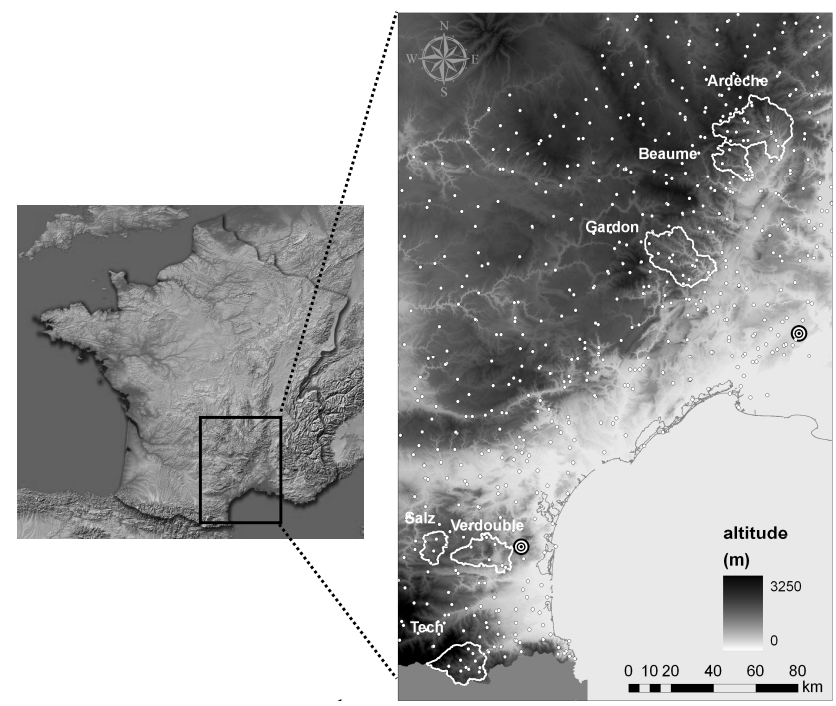

Fig. 2. (Left) Topography of France (source: SRTM image, NASA/JPL). (Right) (white contour) Topography of the six catchments of interest (France) from BD TOPO ${ }^{\circledR}$ IGN, (concentric circles) hydrometeorological radars, (white dots) operational rain gauges.

2008. ${ }^{\odot}($ SCHAPI $\left.)\right)$. The mean elevation ratios of the whole river basins are above $0.025 \mathrm{~m} \mathrm{~m}^{-1}$.

The Salz and Verdouble catchment areas mainly develop on sedimentary formations contrarily to the other catchments, where substrates develop on metamorphic and plutonic terrains. Soil thicknesses and textures were available from the BDSol-LR (Robbez-Masson et al., 2002) (IGCS BDSol-LR - version no. 2006, INRA - Montpellier SupAgro) (Table 1). Soil-saturated hydraulic conductivities, saturated water contents and soil suctions are determined with (Rawls and Brakensiek, 1985) pedotransfer functions as proposed by Manus et al. (2009). Braud et al. (2010) and Roux et al. (2011) highlight the importance of soil thickness and texture on hydrological process and catchment flood response. It has recently been shown with a comparative hydrologic study that flood response in Austria is significantly controlled by geology (Gaál et al., 2012).

For the Gardon, Beaume and Ardèche catchments, vegetation is dense and mainly composed of chestnut trees, pasture, holm oaks, conifers, waste land and garrigue. Chestnut trees are located in the upstream area and on the south-facing slopes (sunny sides or adret), while forested garrigues and holm oaks are located in the downstream area and on the north-facing slopes (shady sides or ubac). The Tech catchment's vegetation is rather dense also, with broadleaved and coniferous forests. Mainly Mediterranean forest, garrigue, holm oaks and vineyards are encountered on the Salz and Verdouble catchments. A vegetation and land use map (Corine Land Cover provided by the Service de l'Observation et des Statistiques (SOeS) of the French 
Table 1. Catchments physiographic properties, elevation ration is height difference divided by longest flow path length, K mean is the mean soil saturated hydraulic conductivity. Hsol is the spatially distributed soil depth estimated from pedologic data.

\begin{tabular}{|c|c|c|c|c|c|c|c|c|c|c|}
\hline Catchments & $\begin{array}{r}\text { Area } \\
\left(\mathrm{km}^{2}\right)\end{array}$ & $\begin{array}{r}\text { Height } \\
\text { diff. } \\
(\mathrm{m})\end{array}$ & $\begin{array}{r}\text { Max. } \\
\text { flow } \\
\text { length } \\
(\mathrm{km})\end{array}$ & $\begin{array}{r}\text { Elevation } \\
\text { ratio } \\
\left(\mathrm{m} \mathrm{m}^{-1}\right)\end{array}$ & $\begin{array}{r}\text { Hsol } \\
\text { min. } \\
(\mathrm{m})\end{array}$ & $\begin{array}{l}\text { Hsol } \\
\max . \\
(\mathrm{m})\end{array}$ & $\begin{array}{r}\text { Hsol } \\
\text { mean } \\
(\mathrm{m})\end{array}$ & $\begin{array}{r}\text { Hsol } \\
\text { std } \\
(\mathrm{m})\end{array}$ & $\begin{array}{r}\text { Soil } \\
\text { volume } \\
\left(\mathrm{m}^{3}\right)\end{array}$ & $\begin{array}{r}K \\
\text { mean } \\
\left(\mathrm{mm} \mathrm{h}^{-1}\right)\end{array}$ \\
\hline Tech (Pas-du-Loup) & 250 & 2730 & 34.5 & 0.079 & 0.00 & 0.69 & 0.16 & 0.13 & $5.3 \times 10^{7}$ & 2.5 \\
\hline Verdouble (Tautavel) & 299 & 915 & 37.0 & 0.025 & 0.08 & 0.63 & 0.33 & 0.16 & $1.0 \times 10^{8}$ & 2.4 \\
\hline Salz (Cassaignes) & 144 & 995 & 17.2 & 0.058 & 0.00 & 0.74 & 0.31 & 0.19 & $4.2 \times 10^{7}$ & 3.9 \\
\hline Gardon (Anduze) & 543 & 1065 & 45.1 & 0.024 & 0.08 & 0.64 & 0.28 & 0.12 & $1.5 \times 10^{8}$ & 05.0 \\
\hline Beaume (Rosières) & 212 & 1360 & 29.0 & 0.047 & 0.05 & 0.49 & 0.25 & 0.07 & $5.2 \times 10^{4}$ & 8.7 \\
\hline Ardèche (Vogüié) & 619 & 1380 & 52.5 & 0.026 & 0.05 & 0.50 & 0.28 & 0.08 & $1.7 \times 10^{8}$ & 8.7 \\
\hline
\end{tabular}

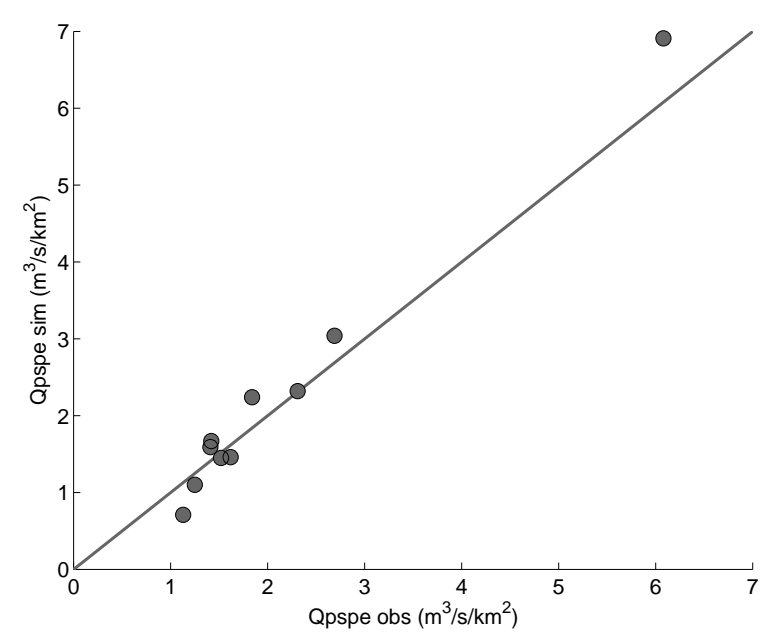

Fig. 3. Simulated peak discharge versus observed peak discharge for validation events with first bisector (blue line).

Ministry of Environment, www.ifen.fr) is used to derive distributed surface roughness.

\section{Preliminary analysis}

Initialization is an important step in the case of flash flood event-based models running on a time window of few days. Soil saturation at the beginning of each event is estimated with SAFRAN-ISBA-MODCOU (SIM), a continuous hydrometeorological model (Habets et al., 2008). This continuous water balance model is run over the whole country on $8 \mathrm{~km} \times 8 \mathrm{~km}$ cells and outputs such as soil moisture with at least daily time step are available. This systematically available spatial-temporal model outputs for catchment initial soil moisture accountancy is chosen. We keep in mind that soil moisture is related to soil parameters in defining catchment soil infiltrability and storage capacity. But an accurate estimation of soil moisture at the catchment scale is still difficult even if combining spatialized superficial remotely
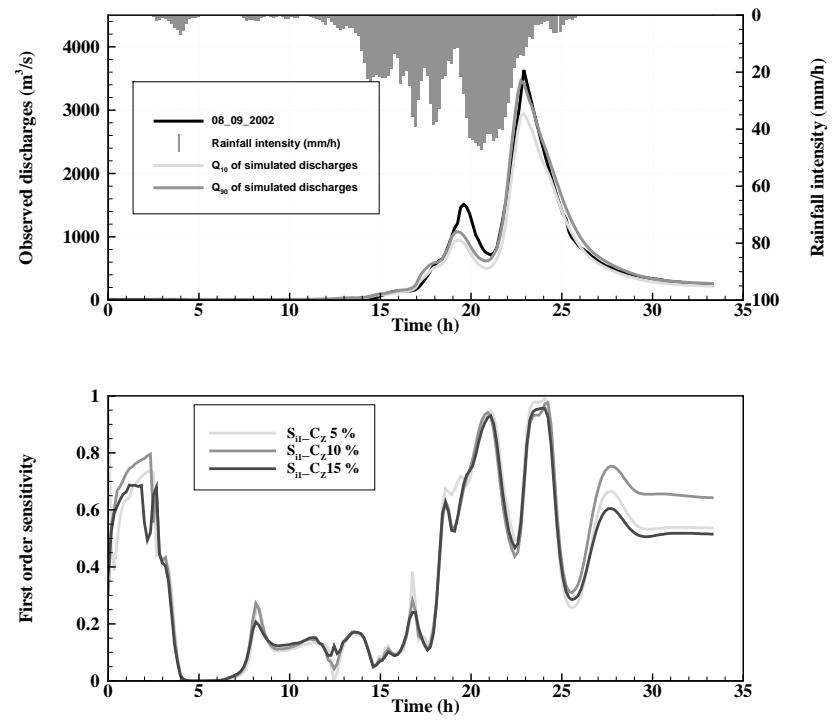

Fig. 4. (Top) Gardon d'Anduze: 8 September 2002 flash flood event and quintiles $Q_{10}$ and $Q_{90}$ of simulated discharges for $\alpha=5,10$ and $15 \%$. (Bottom) First-order effects for $C_{Z}$ and three sampling ranges.

sensed data and numerous in situ point measurements lead to promising results (Brocca et al., 2012; Albergel et al., 2012). An estimation of uncertainty for soil moisture model outputs would be welcome but it remains a hard task given that a very good knowledge of soil properties and structure seems to be required.

\subsection{Calibrated parameter sets}

In order to avoid a model overparameterization, spatial patterns of several parameters are derived from soil surveys, and a unique correction coefficient is then applied to each parameter map. This approach has been chosen for three parameters - namely the distributed saturated hydraulic conductivity $K$, the lateral transmissivity $T_{0}$ and soil thicknesses $Z$. The calibration procedure consists in estimating the following: 

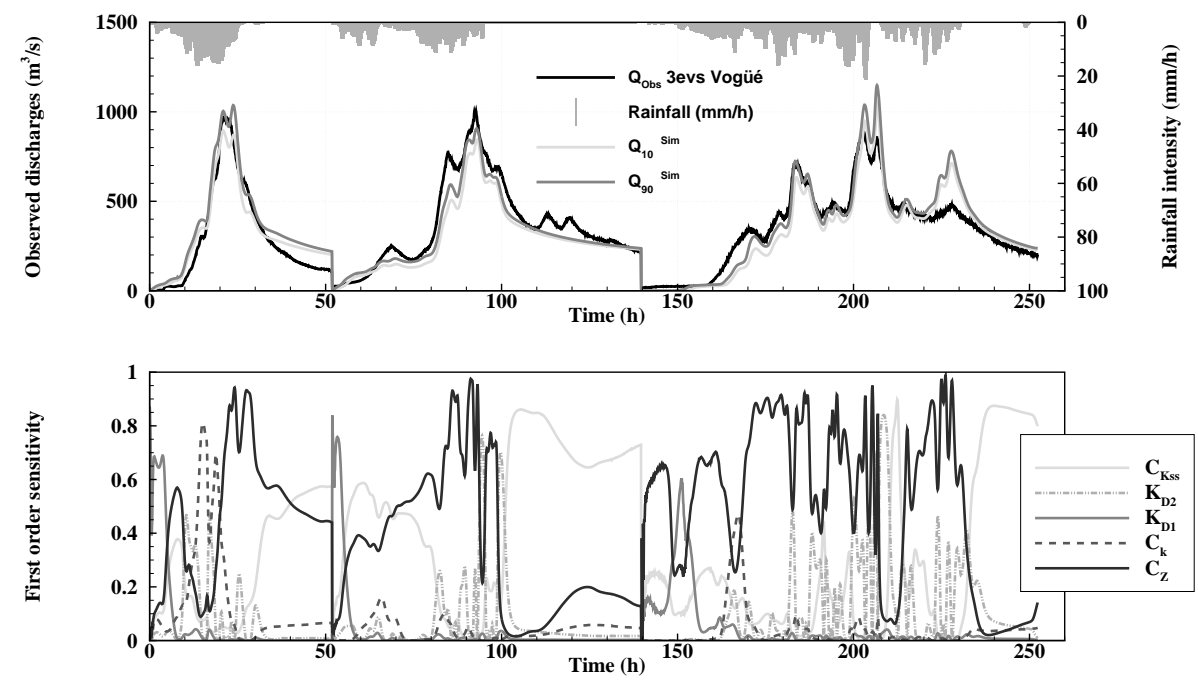

Fig. 5. (Top) Ardèche at Vogüé $\left(619 \mathrm{~km}^{2}\right)$ : 20 October 2008, 31 October 2008 and 3 November 2011 flash flood events and quintiles $Q_{10}$ and $Q_{90}$ of simulated discharge. (Bottom) First-order effects representing first-order contribution and partial variances out of model output variance $(-)$.
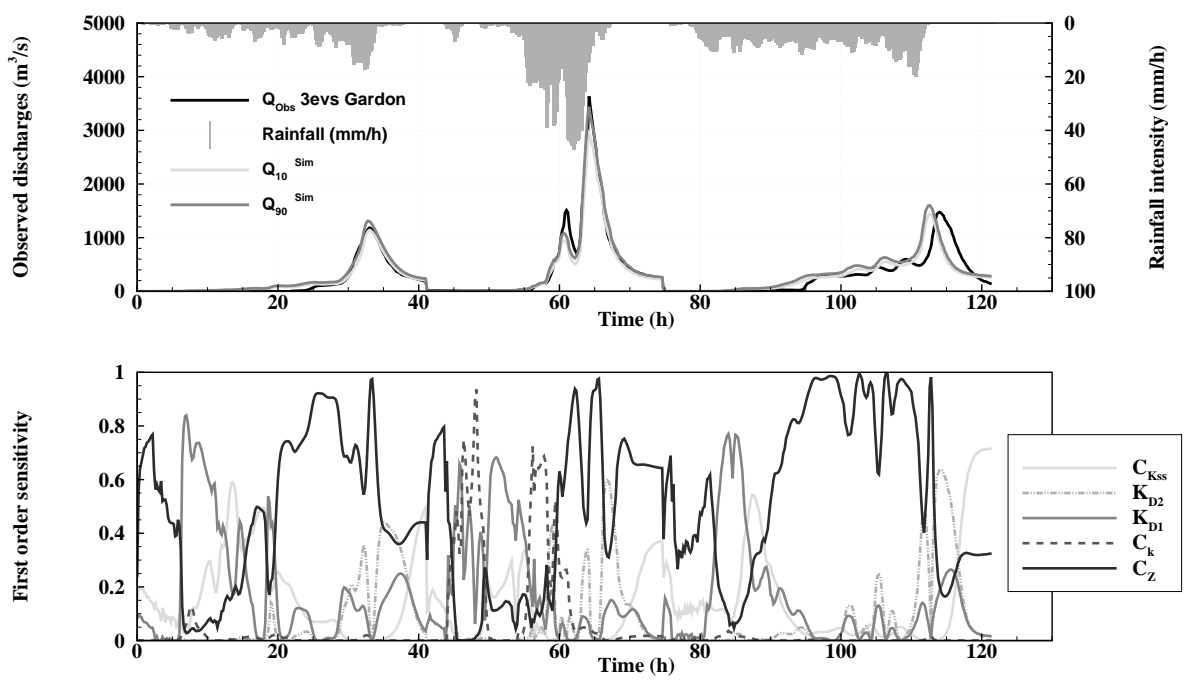

Fig. 6. (Top) Gardon at Anduze $\left(543 \mathrm{~km}^{2}\right)$ : 28 September 2000, 8 September 2002 and 18 October 2006 flash flood events and quintiles $Q_{10}$ and $Q_{90}$ of simulated discharge. (Bottom) First-order effects.

three coefficients of correction for spatialized data; one for the saturated hydraulic conductivities, named $C_{K}$; another one, $C_{\mathrm{KSS}}$, for the lateral subsurface flow transmissivity $\left(T_{0}\right)$; and the last one for the soil thicknesses, named $C_{Z}$, the Strickler roughness of the main channel $K_{\mathrm{D} 1}$ and the Strickler roughness of the overbank of the drainage network $K_{\mathrm{D} 2}$ (Roux et al., 2011; Garambois et al., 2012a). Concerning the transmissivity $T_{0}$ the spatial variability is taken from the hydraulic conductivity map. Catchment parameter sets that will be used in this paper are given in Table 2. For each catchment, model calibration is performed by estimating a parameter set over several flash flood events (Table 3); that is, a cost function equal to 1-Nash is minimized over multiple flood events (called global Nash hereafter). The minimization technique is a BFGS (Broyden-Fletcher-Goldfarb-Shanno) algorithm considering multiple starting points in the parameter space. The validation is performed on other available flash flood events, and efficiencies are given in Table 3. We do not pretend to have reached "the best parameter sets" for these catchments, the word optimal needing to be defined in function of the modeling goals, especially if modeling (and data) uncertainties and parameter values are considered variable in time. Nevertheless, performances of the model on the events considered in calibration and in validation are rather high over the six catchments of interest (Table 3). Performance decrease is slight for the whole catchment set from calibration 
to validation with mean Nash values of 0.86 and 0.7 , respectively (Table 3).

\subsection{Selected validation flash flood events for sensitivity analysis}

Monitoring flash floods remains a hard exercise (Borga et al., 2008) since conventional measurement networks of rain and river discharges are not able to sample effectively because of scales problems. Hydrometric data are provided by the SCHAPI (Service Central Hydrométéorologique d'Appui à la Prévision des Inondations - French central flood forecast center) and the SPC Grand Delta located in Nîmes and the SPC Mediterranée Ouest located in Carcassone (Service de Prévision des Crues - Regional flood forecast center). Radar rainfall measurements (Météo France - Nîmes radar) combined with rain gauge data are available at $5 \mathrm{~min}$ time steps and $1 \mathrm{~km} \times 1 \mathrm{~km}$ spatial resolution since 2002 for the whole French Mediterranean region and since 1994 on the Cévennes region. Few floods of several years return period have been experienced in the six catchments of interest catchment since 2002 (resp. 1994). In this paper an interesting set of 10 validation events is used. This constitutes a large validation dataset given the scarcity of data about flash flood events in general.

Validation event hydrographs with distinct shapes represent contrasted hydrological responses to different resonances between rainfall spatio-temporal distribution and catchment physiographic properties, in other words a catchment's spatial and temporal dampening effect (cf. Table 4 and Figs. 5 to 8):

- single-peak medium events (15 March 2011 at Pas-duLoup, 20 December 2000 at Cassaignes, 28 September 2000 and 18 October 2006 with a slow-rising limb at Anduze),

- single-peak medium events with slow-rising and/or declining limb (16 November 2006 at Rosières, 20 October 2008 and 31 October 2008 at Voguié),

- multipeak events (15 March 2011 at Tautavel, 3 November 2011 at Vogüé),

- and a $50 \mathrm{yr}$ return period extreme event (8 September 2002 at Anduze).

In addition to classical normalized least-squares criterion, $L_{\mathrm{NP}}$ (Table 5) considers features characterizing the flood peak (discharge value and time to peak) (Roux et al., 2011). Efficiencies for these validation events considered in the following are high, with $L_{\mathrm{NP}}$ efficiencies above 0.73 and of 0.83 on average. Mean peak flow discharge and timing relative errors are inferior to 0.17 and 0.13 .

Most validation events present observed specific peak discharge ranging from 1.13 to $2.69 \mathrm{~m}^{3} \mathrm{~s}^{-1} \mathrm{~km}^{-2}$ (Fig. 3). The extreme event of September 2002 at Anduze has an estimated peak discharge of $6.08 \mathrm{~m}^{3} \mathrm{~s}^{-1} \mathrm{~km}^{-2}$. Differences between simulated and observed discharges are satisfactory with an $R^{2}$ of 0.87 with respect to the first bisector, so the model presents no significant bias for these catchments floods.

Performances of the model on the events considered in calibration and in validation are rather high over the six catchments of interest and may therefore be considered as sufficient for flash flood prediction purpose. Yet we would like to point out that the aim of this paper is not to test the predictive performances of the model, which would require a larger set of events under various conditions.

\subsection{Evaluation of temporal sensitivity analysis method}

Using the variance-based sensitivity analysis method described in Sect. 2, a region of the parameter space around calibration point is explored and sensitivity indices are estimated in order to analyze the relative importance of MARINE model inputs for validation events. Concerning the locality (in the parameter space) of the proposed analysis, global sensitivity analysis of MARINE model has already been tested (Roux et al., 2011). The present paper investigates the other types of information that a temporal sensitivity analysis can provide. The answer to the question of how sensitivities change for different parameter sets is not straightforward, and further studies would be welcome - for example with several parameter sets for one catchment.

For each catchment we use the calibrated parameter sets of Section 4.1 for validation events and temporal parameter sensitivity $\left(S_{i}^{\prime} s\right)$ calculation. The tested input factors are the five calibrated ones: three coefficients of correction $C_{K}$, $C_{\mathrm{Kss}}, C_{Z}$, the Strickler roughness of the overbank of the drainage network $K_{\mathrm{D} 2}$ and the main channel roughness coefficient $K_{\mathrm{D} 1}$.

We use a 1024-parameter-set quasi-random Monte Carlo sample. The $S_{i}^{\prime} s$ are calculated for MARINE discharge at each time step in a $\pm \alpha \%$ interval around the nominal parameter value with the method described in section above. Ideally for each parameter, the sampling range around nominal parameter value could be defined with information on parameter posterior distribution function with the strength of methods such as Markov chain Monte Carlo (Smith and Marshall, 2008; Vrugt et al., 2009; Kuczera et al., 2010). These methods are, however, too computationally demanding for our extended study and the choice of $\alpha$ is tested here.

From 5 to $15 \%$ around the nominal parameter values, the choice of $\alpha$ reveals to have a rather limited influence on temporal dynamics of parameter sensitivity (TEDPAS) and their values (Table 6). The first-order effect $S_{i 1}$ measures the relative importance of an individual input variable $X_{i}$ in driving the uncertainty. Parameter ranking remains the same with a total standard error lower than 0.03. Low error and high first-order metamodel $R^{2}$ attest the good convergence of the SDR algorithm on the 1024 sample size. $S_{i}$ values quantifying model output sensitivity to each parameter are quite 
Table 2. Catchment parameter sets and Nash efficiencies for multiple events calibration.

\begin{tabular}{lrrrrrrr}
\hline Catchments & $\begin{array}{r}\text { Area } \\
\left(\mathrm{km}^{2}\right)\end{array}$ & $C_{Z}$ & $C_{K}$ & $C_{\mathrm{KSS}}$ & $K_{\mathrm{D} 1}$ & $K_{\mathrm{D} 2}$ & $\begin{array}{r}\text { Nlobal } \\
\text { Nash }\end{array}$ \\
\hline Tech (Pas-du-Loup) & 250 & 4.34 & 11.0 & 1515 & 4.83 & 3.24 & 0.90 \\
Verdouble (Tautavel) & 299 & 1.30 & 15.0 & 4486 & 5.00 & 3.99 & 0.88 \\
Salz (Cassaignes) & 144 & 0.95 & 20.0 & 5595 & 5.00 & 2.54 & 0.89 \\
Gardon (Anduze) & 543 & 4.60 & 10.3 & 4540 & 11.70 & 9.70 & 0.88 \\
Beaume (at Rosières) & 212 & 5.30 & 7.40 & 3712 & 21.40 & 14.70 & 0.80 \\
Ardèche (at Vogüé) & 619 & 3.40 & 2.10 & 4891 & 10.00 & 19.10 & 0.80 \\
Calibration ranges & & $0.1-10$ & $0.1-15$ & $100-10000$ & $4-40$ & $2-30$ & \\
\hline
\end{tabular}

Table 3. Number of events used for calibration and validation, event and global model efficiencies of parameter sets presented in Table 2.

\begin{tabular}{lrrrrrrrr}
\hline & $\begin{array}{r}\text { Number of } \\
\text { calibration } \\
\text { events }\end{array}$ & $\begin{array}{r}\text { Nash } \\
\text { global } \\
\text { calibration }\end{array}$ & $\begin{array}{r}\text { Min. event } \\
\text { Nash } \\
\text { calibration }\end{array}$ & $\begin{array}{r}\text { Max. event } \\
\text { Nash } \\
\text { calibration }\end{array}$ & $\begin{array}{r}\text { Number of } \\
\text { validation } \\
\text { events }\end{array}$ & $\begin{array}{r}\text { Mean Nash } \\
\left(L_{\text {NP }}\right) \\
\text { validation }\end{array}$ & $\begin{array}{r}\text { Min. event } \\
\text { Nash }\left(L_{\text {NP }}\right) \\
\text { validation }\end{array}$ & $\begin{array}{r}\text { Max. event } \\
\text { Nash }\left(L_{\mathrm{NP}}\right) \\
\text { validation }\end{array}$ \\
\hline Tech (Pas-du-Loup) & 3 & 0.90 & 0.80 & 0.91 & 3 & $0.50(0.41)$ & $0.20(0.00)$ & $0.70(0.73)$ \\
Verdouble (Tautavel) & 4 & 0.88 & 0.74 & 0.95 & 2 & $0.74(0.73)$ & $0.63(0.66)$ & $0.82(0.79)$ \\
Salz (Cassaignes) & 3 & 0.88 & 0.83 & 0.90 & 1 & $0.76(0.75)$ & $0.76(0.75)$ & $0.76(0.75)$ \\
Gardon (Anduze) & 6 & 0.88 & 0.60 & 0.95 & 4 & $0.86(0.88)$ & $0.60(0.80)$ & $0.97(0.97)$ \\
Beaume (Rosières) & 3 & 0.80 & 0.57 & 0.87 & 3 & $0.49(0.72)$ & $0.26(0.58)$ & $0.64(0.82)$ \\
Ardèche (Vogüé) & 5 & 0.80 & 0.60 & 0.94 & 3 & $0.88(0.86)$ & $0.85(0.73)$ & $0.93(0.96)$ \\
Average & 4 & 0.86 & 0.69 & 0.92 & 3 & $0.70(0.72)$ & $0.55(0.59)$ & $0.80(0.81)$ \\
\hline
\end{tabular}

similar, with relative variation lower than $5 \%$ for the three alpha values.

Figure 4 shows a limited influence of sampling range on temporal sensitivity index to $C_{Z}$, which is the most sensitive parameter on average. $S_{i 1} C_{Z}$ estimation differences are lower than $15 \%$ after model initialization and during hydrograph late recession, and lower than $5 \%$ for the rest of the simulation, especially when most hydrographs are peaking ( $t=20$ to $27 \mathrm{~h}$ ).

Small to large parameter sampling ranges show limited influence on sensitivity calculations with similar event firstorder effects for each parameter. Observations made after testing $S_{i}$ estimation lead us to select a $\pm 10 \%$ sampling interval around the nominal parameter values for TEDPAS calculation with small errors in the following.

Temporal sensitivity presents the same pattern for the different sampling ranges with low standard errors. Rapid oscillations (Fig. 4, bottom) can be apportioned to strong temporal gradients in nonzero-simulated discharges and different trends between the 1024 hydrographs. Let us recall that the MARINE model runs on a $200 \mathrm{~m}$ mesh and a time step of a few seconds verifying CFL (Courant-Friedrichs-Lewy) conditions, it is then not surprising to obtain such temporal variations in sensitivities with $5 \mathrm{~min}$ time resolution radar rainfalls inputs and observed discharges. Important oscillations can also be remarked on TEDPAS calculated for TOPMODEL and WaSIM-ETH models (Reusser et al., 2011).

\section{Temporal analysis of flash flood model behavior}

\subsection{Event-averaged first-order effects}

This measure indicates the relative importance of an individual input variable $X_{i}$ in driving the uncertainty. It is good to notice that sensitivities are not calculated with a cost function but with simulated discharge at the outlet. Different phases in catchment saturation and runoff generation are aggregated into discharge and their temporal variation is reported in terms of the partial variance explained by an input factor at this time step. For example, a value of around 0.8 at $23 \mathrm{~h}$ when most hydrographs (1024 parameter sets sample) are peaking indicates that $80 \%$ of the observed variation between model runs can be explained by this parameter (Fig. 4).

First-order sensitivity indices and the related standard error and first-order metamodel $R^{2}$ constitute basic outputs of SDR method; in a first time they are averaged on each validation event for the catchments of interest (Table 7). $R^{2}$ of first-order metamodel are above 0.93 and indicate a good convergence of the method. Event-averaged standard error on $S_{i}^{\prime} s$ is 0.03 and the following parameter ranking $C_{Z}>C_{\mathrm{KSS}}$ $>K_{\mathrm{D} 1}>K_{\mathrm{D} 2}>C_{K}$ is obtained for the whole catchment flood dataset. According to results displayed in (Table 7), soil profile storage capacity controlled by parameter $C_{Z}$ is the most important input factor for 8 of the 10 events considered. Soil storage capacity has a large impact on soil saturation dynamics and thus runoff generation mechanisms. Relation 

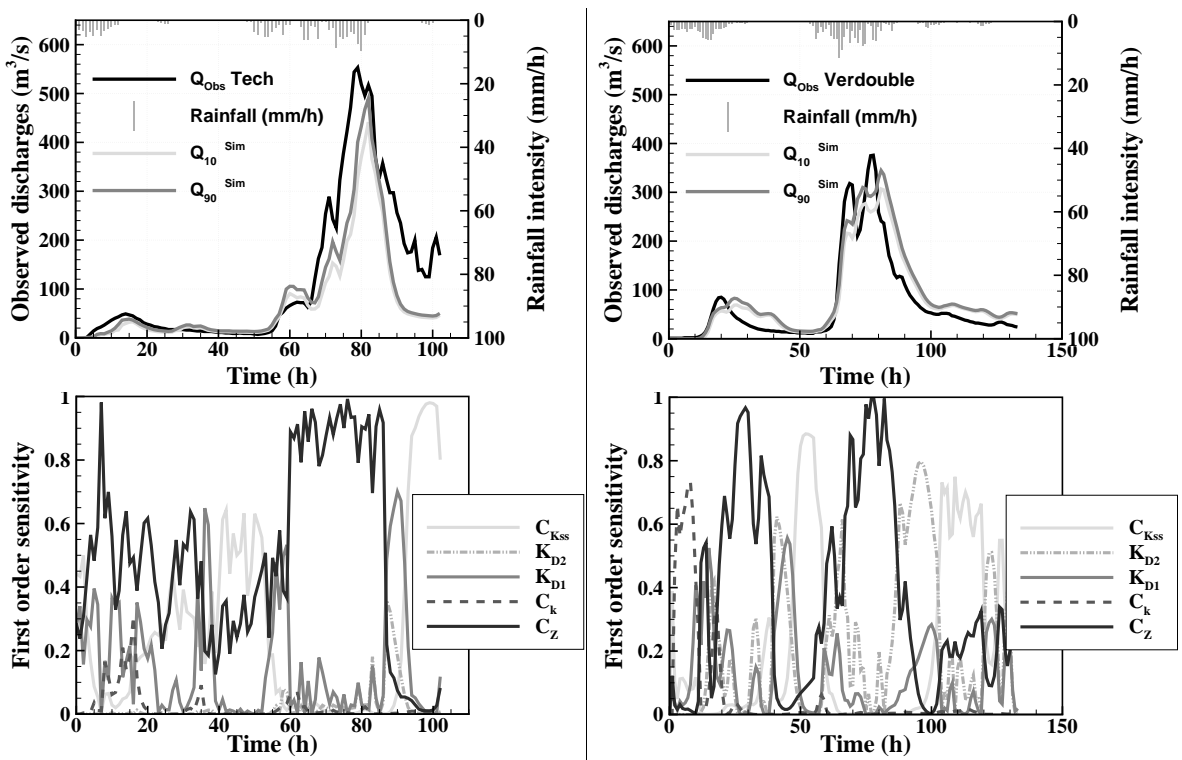

Fig. 7. (Top)Flash flood event of 15 March 2011 and $Q_{10}$ and $Q_{90}$ quintiles of simulated discharge for (left) the Tech at Pas-du-Loup $\left(250 \mathrm{~km}^{2}\right)$ and (right) the Verdouble at Tautavel $\left(299 \mathrm{~km}^{2}\right)$. (Bottom) First-order effects.

Table 4. Validation events characteristics in increasing order of specific peak flow. Mean initial soil moisture is the spatially averaged daily SIM output over a catchment.

\begin{tabular}{lrrrrr}
\hline & $\begin{array}{r}\text { Area } \\
\left(\mathrm{km}^{2}\right)\end{array}$ & $\begin{array}{r}\text { Validation } \\
\text { events }\end{array}$ & $\begin{array}{r}\text { Mean } \\
\text { initial soil } \\
\text { moisture }(\%)\end{array}$ & $\begin{array}{r}\text { Specific } \\
\text { peak flow } \\
\left(\mathrm{m}^{3} \mathrm{~s}^{-1} \mathrm{~km}^{-2}\right)\end{array}$ & $\begin{array}{r}\text { Cumulated } \\
\text { rainfall } \\
(\mathrm{mm})\end{array}$ \\
\hline Beaume (Rosières) & 212 & 16 November 2006 & 56 & 1.1 & 111 \\
Verdouble (Tautavel) & 299 & 15 March 2011 & 52 & 1.2 & 217 \\
Gardon (Anduze) & 543 & 28 September 2000 & 56 & 1.4 & 203 \\
Salz (Cassaignes) & 144 & 20 December 2000 & 48 & 1.5 & 141 \\
Ardèche (Vogüé) & 619 & 3 November 2011 & 50 & 1.5 & 370 \\
Ardèche (Vogüé) & 619 & 20 October 2008 & 48 & 1.6 & 195 \\
Ardèche (Vogüé) & 619 & 31 October 2008 & 59 & 1.6 & 211 \\
Tech (Pas-du-Loup) & 250 & 15 March 2011 & 62 & 2.2 & 270 \\
Gardon (Anduze) & 543 & 18 October 2006 & 62 & 2.6 & 237 \\
Gardon (Anduze) & 543 & 8 September 2002 & 58 & 6.7 & 284 \\
\hline
\end{tabular}

between soil profile storage capacity and flood event magnitude seems nonmonotonous according to parameters sensitivities (Tables 4 and 7). Previous global sensitivity analysis studies already show that the model response is sensitive to $C_{Z}$ (Bessière, 2008; Roux et al., 2011), which seems to indicate that sensitivity may change little for a different optimal parameter set.

For the other parameters, relation is monotonous. The relative importance of catchment infiltrability $\left(C_{K}\right)$ and friction in the drainage network (i.e., $K_{\mathrm{D} 1}$ and $K_{\mathrm{D} 2}$, channel and overbank correction coefficients) increases with the magnitude of the event. On the contrary, given the reduction of the proportion subsurface flow represents, the influence of subsurface flow velocity (i.e., $C_{\mathrm{KSS}}$ ) decreases with the magnitude of the event (Table 3 ). $C_{\mathrm{KSS}}$ is particularly sensitive for the Ardèche and Salz catchments. Let us remark that the sum of first-order effects $\sum_{i} S_{i}$ is lower than one with low standard errors (Table 7) and the equality would mean that the model is additive (Saltelli et al., 2000).

\subsection{Temporal evolution of first-order effects}

In order to analyze the temporal dynamics of model input factors influence on the simulated discharge for the 10 flood events on six catchments, the explored variability of model response (top) and the temporally variable sensitivity indices (bottom) are represented on Figs. 5 to 8. Whatever the rainfall patterns and volume, for some aspects of the model response, catchments behaviors characterized by the first-order 

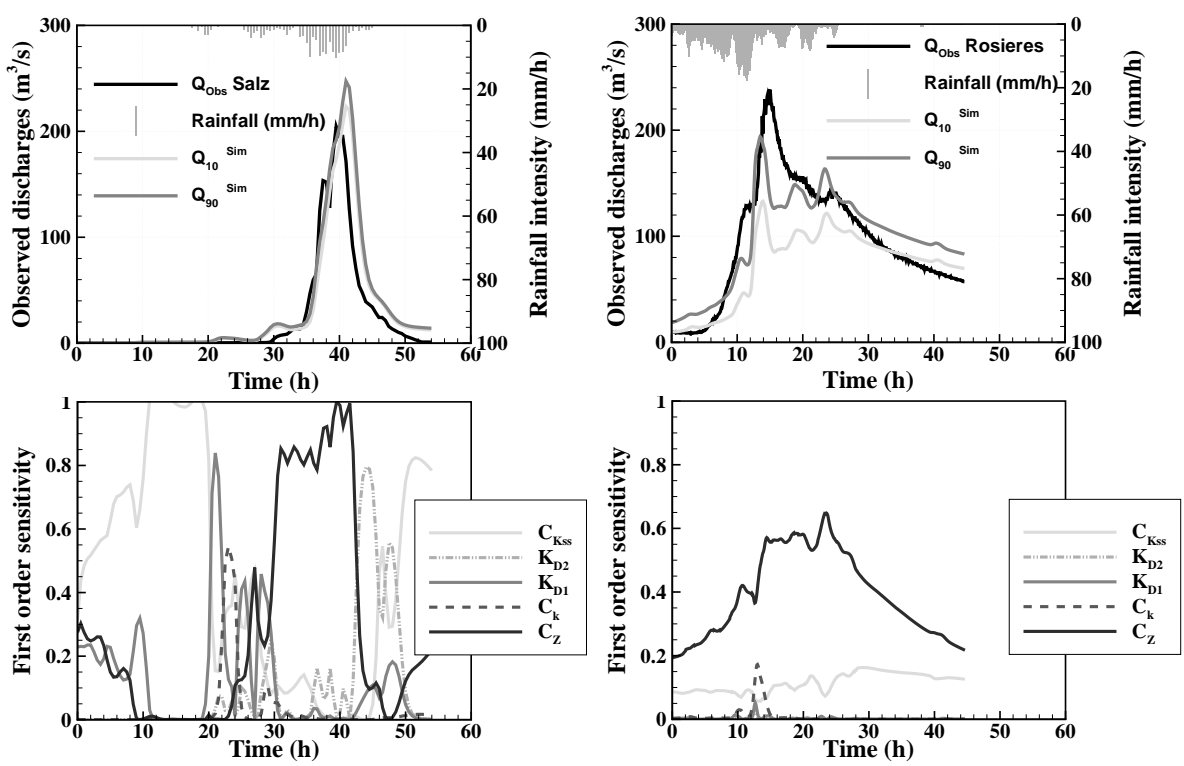

Fig. 8. (Top) $Q_{10}$ and $Q_{90}$ quintiles of simulated discharge on (left) 20 December 2000 for the Salz at Cassaignes (144 $\left.\mathrm{km}^{2}\right)$, (right) 16 November 2006 for the Beaume at Rosières $\left(212 \mathrm{~km}^{2}\right)$. (Bottom) First-order effects.

Table 5. Validation events and efficiencies in terms of $\Delta \mathrm{Q}$ comparing simulated and observed peak discharge $Q_{\mathrm{P}}^{\mathrm{S}}$ and $Q_{\mathrm{P}}^{\mathrm{o}}$, and $\Delta T$ comparing simulated and observed peak time normalized by concentration time $T_{\mathrm{C}}^{\mathrm{o}}$, determined from Bransby formula $T_{\mathrm{C}}^{\mathrm{O}}=\frac{21.3 L}{A^{0.1} S^{0.2}}$, where $L$ is channel length $(\mathrm{m}), A$ is watershed area $\left(\mathrm{m}^{2}\right)$ and $S$ is linear profile slope $\left(\mathrm{m} \mathrm{m}^{-1}\right)$.

\begin{tabular}{|c|c|c|c|c|c|c|}
\hline Catchments & $\begin{array}{c}\text { Area } \\
\left(\mathrm{km}^{2}\right)\end{array}$ & $\begin{array}{r}\text { Validation } \\
\text { events }\end{array}$ & 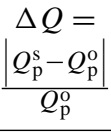 & $\begin{array}{c}\Delta T= \\
\frac{\mid T_{\mathrm{p}}^{\mathrm{s}}-T_{\mathrm{p}}^{\mathrm{o}}}{} \mid \\
T_{C}^{\mathrm{o}}\end{array}$ & Nash & $\begin{array}{c}L_{\mathrm{NP}}=\frac{1}{3}(\mathrm{Nash}+ \\
(1-\Delta Q)+(1-\Delta T))\end{array}$ \\
\hline Tech (Pas-du-Loup) & 250 & 15 March 2011 & 0.15 & 0.32 & 0.70 & 0.73 \\
\hline Verdouble (Tautavel) & 299 & 15 March 2011 & 0.13 & 0.32 & 0.82 & 0.79 \\
\hline Salz (Cassaignes) & 144 & 20 December 2000 & 0.18 & 0.32 & 0.76 & 0.75 \\
\hline \multirow{3}{*}{ Gardon (Anduze) } & \multirow{3}{*}{543} & 28 September 2000 & 0.03 & 0.02 & 0.95 & 0.97 \\
\hline & & 8 September 2002 & 0.12 & 0.00 & 0.97 & 0.95 \\
\hline & & 18 October 2006 & 0.03 & 0.15 & 0.60 & 0.80 \\
\hline Beaume (Rosières) & 212 & 16 November 2006 & 0.32 & 0.10 & 0.64 & 0.75 \\
\hline \multirow{3}{*}{ Ardèche (Vogüé) } & \multirow{3}{*}{619} & 20 October 2008 & 0.02 & 0.02 & 0.93 & 0.96 \\
\hline & & 31 October 2008 & 0.13 & 0.04 & 0.87 & 0.89 \\
\hline & & 3 November 2011 & 0.23 & 0.40 & 0.85 & 0.73 \\
\hline Average & & & 0.13 & 0.17 & 0.81 & 0.83 \\
\hline
\end{tabular}

sensitivity indices are similar. First, before rainfall starts, $C_{Z}$, $C_{\mathrm{KSS}}$ and $K_{\mathrm{D} 1}-$ i.e., soil depths, lateral subsurface flow and main channel roughness - explain most of the variability because the initial soil water content (above $48 \%$, Table 4) activates subsurface flow and exfiltration in the drainage network. Only the main channel represented by $K_{\mathrm{D} 1}$ is concerned by these small amounts of water at the outlet (a few $\mathrm{m}^{3} \mathrm{~s}^{-1}$ ).

Then we can distinguish the 16 November 2006 event at Rosières (Fig. 8, right), the smallest one in terms of spe- cific discharge, from the nine others obviously activating all model flow components. This event is underestimated by MARINE and is characterized by an important sensitivity to $C_{Z}$, especially at peak time and early recession (11 to $22 \mathrm{~h}$ ) of the hydrograph. $C_{K}$ and $K_{\mathrm{D} 1}$ play a small role during the rising limb. Moreover, while the influence of the parameter driving infiltrability (i.e., $C_{K}$ ) is low, subsurface flow represented by parameter $C_{\mathrm{KSS}}$ plays an important role ( $10 \%$ of total variance). Only "minor flow components" are activated 
Table 6. Gardon d'Anduze: 8 September 2002 flash flood event, first-order effects and standard error averaged in time, and first-order metamodel $R^{2}$ for different sampling ranges around nominal parameter values.

\begin{tabular}{lcccccccc}
\hline$\alpha$ & $S_{i 1-} C_{Z}$ & $S_{i 1-} C_{K}$ & $S_{i 1} C_{\mathrm{KSS}}$ & $S_{i 1-K_{\mathrm{D} 1}}$ & $S_{i 1-} K_{\mathrm{D} 2}$ & $\operatorname{Sum}\left(S_{i 1}\right)$ & $\operatorname{Sum}\left(S_{i 1 \_ \text {_td_err }}\right)$ & $R^{2}$ Sum $\left(S_{i 1}\right)$ \\
\hline $\pm 5 \%$ & 0.392 & 0.183 & 0.119 & 0.198 & 0.091 & 0.983 & 0.020 & 0.972 \\
$\pm 10 \%$ & 0.413 & 0.170 & 0.109 & 0.195 & 0.079 & 0.967 & 0.028 & 0.975 \\
$\pm 15 \%$ & 0.376 & 0.169 & 0.117 & 0.196 & 0.081 & 0.940 & 0.030 & 0.971 \\
\hline
\end{tabular}

Table 7. First-order effects (-), standard error and first-order metamodel $R^{2}$ averaged in time for each event of the validation set sorted in ascending order of specific peak flow. For each event 1024 events are analyzed.

\begin{tabular}{|c|c|c|c|c|c|c|c|c|c|c|}
\hline Catchments & $\begin{array}{c}\text { Area } \\
\left(\mathrm{km}^{2}\right)\end{array}$ & Validation events & $S_{i 1-} C_{Z}$ & $S_{i 1-} C_{K}$ & $S_{i 1-} C_{\mathrm{KSS}}$ & $S_{i 1-} K_{\mathrm{D} 1}$ & $S_{i 1-} K_{\mathrm{D} 2}$ & $\begin{array}{l}\text { Sum } \\
\left(S_{i 1}\right)\end{array}$ & $\begin{array}{c}\text { Sum } \\
\left(S_{\left.i 1 \_ \text {stdev }\right)}\right.\end{array}$ & $R^{2}$ \\
\hline Beaume (Rosières) & 212 & 16 November 2006 & 0.73 & 0.00 & 0.23 & 0.00 & 0.00 & 0.979 & 0.038 & 0.99 \\
\hline Verdouble (Tautavel) & 299 & 15 March 2011 & 0.36 & 0.06 & 0.22 & 0.13 & 0.22 & 0.992 & 0.021 & 0.97 \\
\hline Gardon (Anduze) & 543 & 28 September 2000 & 0.49 & 0.01 & 0.17 & 0.20 & 0.07 & 0.943 & 0.056 & 0.94 \\
\hline Salz (Cassaignes) & 144 & 20 December 2000 & 0.29 & 0.03 & 0.42 & 0.11 & 0.09 & 0.941 & 0.038 & 0.99 \\
\hline Ardèche (Vogüé) & 619 & 3 November 2011 & 0.51 & 0.04 & 0.27 & 0.05 & 0.13 & 0.997 & 0.019 & 0.98 \\
\hline Ardèche (Vogüé) & 619 & 20 October 2008 & 0.47 & 0.15 & 0.23 & 0.07 & 0.07 & 0.993 & 0.016 & 0.99 \\
\hline Ardèche (Vogüé) & 619 & 31 October 2008 & 0.33 & 0.04 & 0.49 & 0.04 & 0.07 & 0.967 & 0.011 & 0.99 \\
\hline Tech (Pas du Loup) & 250 & 15 March 2011 & 0.49 & 0.02 & 0.26 & 0.16 & 0.02 & 0.948 & 0.046 & 0.94 \\
\hline Gardon (Anduze) & 543 & 18 October 2006 & 0.57 & 0.00 & 0.15 & 0.14 & 0.08 & 0.947 & 0.035 & 0.93 \\
\hline Gardon (Anduze) & 543 & 8 September 2002 & 0.41 & 0.17 & 0.11 & 0.20 & 0.08 & 0.966 & 0.028 & 0.98 \\
\hline Average & & & 0.43 & 0.05 & 0.24 & 0.11 & 0.08 & 0.92 & 0.034 & 0.92 \\
\hline
\end{tabular}

for that catchment and event - i.e., moderate solicitation of flow components without floodplain invasion.

At the beginning of rainfalls, and during heavy rainfalls, a similar general sensitivity pattern can be found for the nine other events (Figs. 5 to 8); most flow components are activated: infiltration, lateral subsurface flow, hillslope runoff, main channel and floodplain flow. The temporal evolution of parameter's influence involves in the following order the different processes: infiltrability, transfer and limitation by maximum soil storage capacity. In fact, $C_{K}$ determining infiltration capacity is sensitive for significant rainfall intensity variations (Fig. 5 at 15 h, Fig. 6 at 47 and 57 h, Fig. 7 (right) at $8 \mathrm{~h}$, Fig. 8 (left) at $25 \mathrm{~h}$ ). Before the hydrograph's rising limb, $K_{\mathrm{D} 1}$, the main channel friction coefficient, drives the uncertainty, and then soil depth coefficient $C_{Z}$ is sensitive, which defines cells total storage capacity. This highlights sensitivity to the soil volume, which influences saturation dynamics and so on to water volumes partitioning among the catchment. Let us remark that $C_{Z}$ explains more than $80 \%$ of model output variance when most hydrographs are peaking.

However, the presence of some peaks of $C_{\mathrm{KSS}}$ influence during simulations (Fig. 5 around 10,60 and 160, 210 and 240 h; Fig. 6 around 15, 55 and 87 h; Fig. 7 (left) around $50 \mathrm{~h}$, (right) around $52 \mathrm{~h}$; Fig. 8 (left) around $15 \mathrm{~h}$ ) can be explained by a significant contribution of subsurface flow. Indeed, $C_{\mathrm{KSS}}$ is the adjustment parameter of soil lateral conductivity for subsurface flow. It can have an impact on simulated discharge by modifying the distribution of soil wa- ter content and thus infiltration dynamics. During recession, $C_{\mathrm{KSS}}$ sensitivity generally increases, which can show the role of subsurface in recession dynamics according to the model.

Let us consider the high $C_{\mathrm{KSS}}$ sensitivities explaining more than $80 \%$ of model output variance for slow recessions in the case of 31 October 2008 and 3 November 2011 floods on the Ardèche at Vogüé for instance (Fig. 5), as for slow hydrograph rising limb in the case of the 15 March 2011 flood of the Verdouble at Tautavel (Fig. 7, right, at $51 \mathrm{~h}$ ) or the 20 December 2000 flood of the Salz at Cassaignes (Fig. 8, left, between 10 and $20 \mathrm{~h}$ )

$K_{\mathrm{D} 2}$ the overbank roughness coefficient is sensitive during late rising and early falling limbs, when saturation is high and a huge amount of water is transferred to the outlet by overbank flow (Fig. 5 around 20, $90 \mathrm{~h}$ and between 170 and 225 h; Fig. 6 around 35, 67 and 115 h; Fig. 7 (left) around $90 \mathrm{~h}$, (right) around 40, 65 and $100 \mathrm{~h}$; Fig. 8 (left) around $45 \mathrm{~h})$.

Finally, it can be remarked that in the case of the 8 September 2002 extreme event at Anduze, a complex catchment behavior reflected by quickly variable and marked sensitivities is caused by an extreme storm in the very lower part of the catchment causing short response delays (more than $400 \mathrm{~mm}$ cumulated rainfall on half of the catchment with maxima greater than $700 \mathrm{~mm}$ located close to the outlet). On the contrary, the 18 October 2006 and 28 September 2000 generating storms hit the medium or upper part of the Gardon d'Anduze catchment with less violence. For these longer rain 

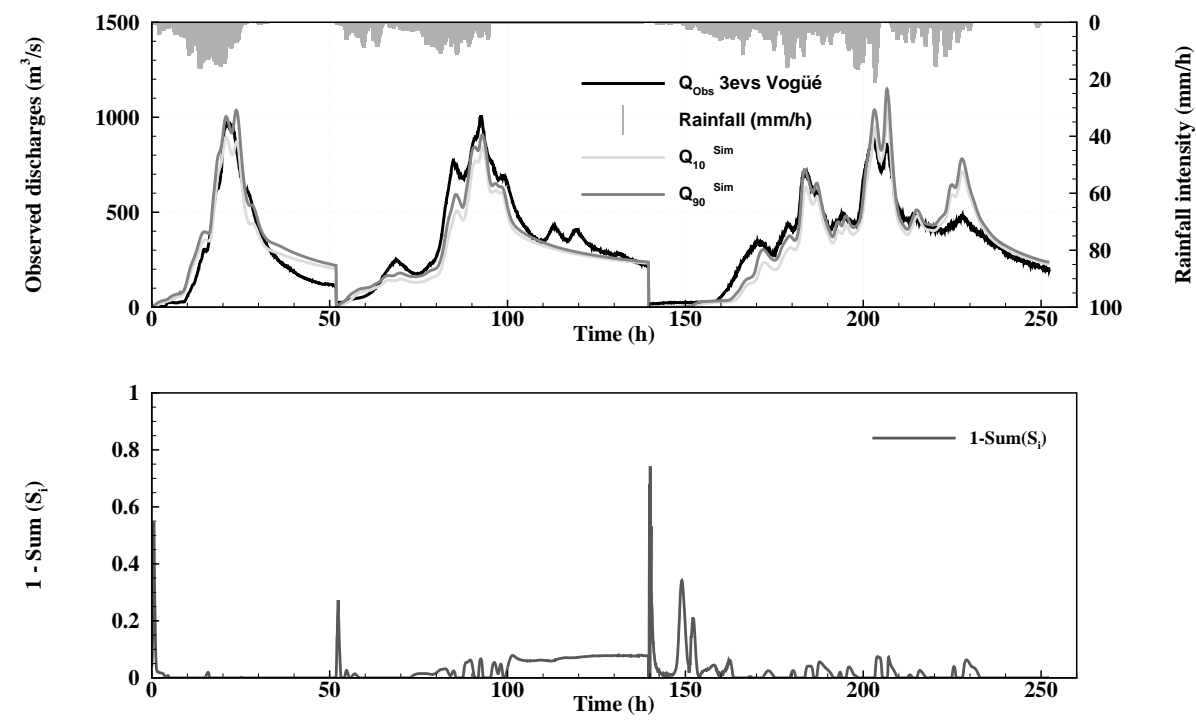

Fig. 9. (Top) Ardèche at Vogüé: 20 October 2008, 31 October 2008 and 3 November 2011 flash flood events and quintiles $Q_{10}$ and $Q_{90}$ of simulated discharge. (Bottom) $1-\sum_{i} S_{i}$.
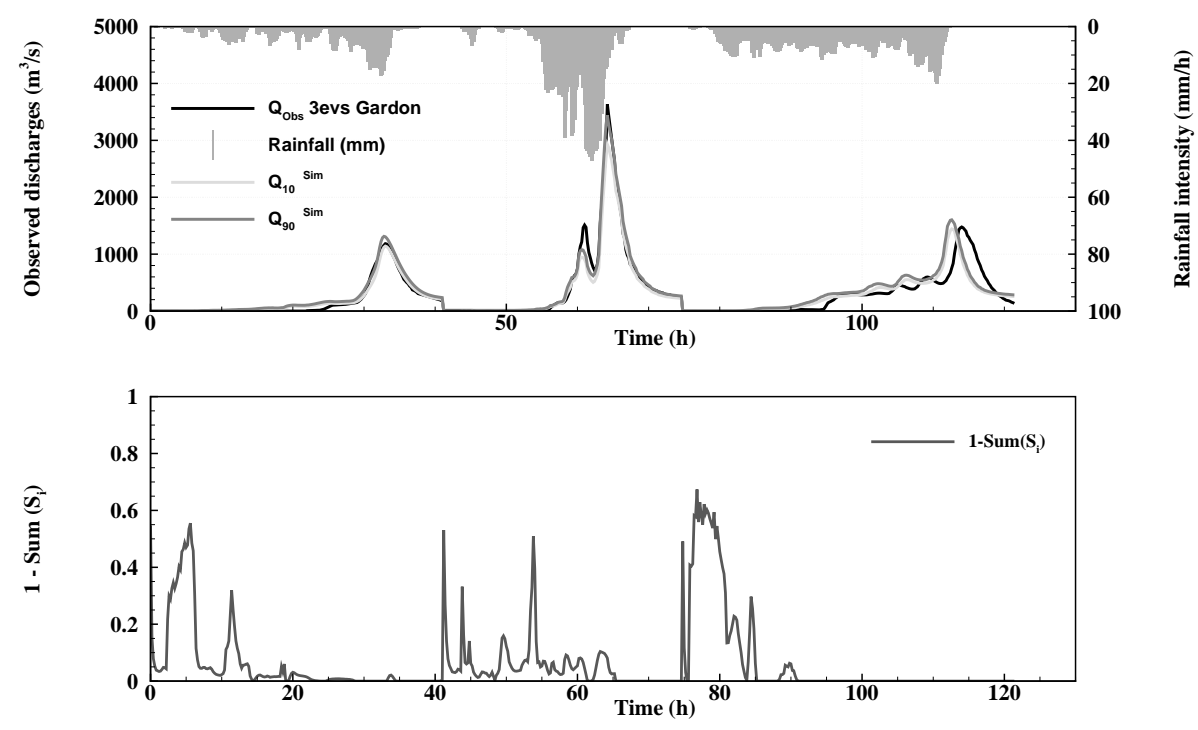

Fig. 10. (Top) Gardon at Anduze: 28 September 2000, 8 September 2002 and 18 October 2006 flash flood events and quintiles $Q_{10}$ and $Q_{90}$ of simulated discharge. (Bottom) $1-\sum_{i} S_{i}$.

events the temporal sensitivities vary more slowly. Moreover, for sensitivity peaks of $C_{Z}$ and then $K_{\mathrm{D} 1}, K_{\mathrm{D} 2}$, (Fig. 6 between 20 and $30 \mathrm{~h}$, and between 95 and $122 \mathrm{~h}$ ) corresponding to rainfall peaks responses, $C_{Z}$ sensitivity stays above the other during the flood. This can be attributed to a catchment spatio-temporal dampening effect: when a storm hits catchment headwaters, a larger soil storage volume is involved in flood generation.

\subsection{Analysis of temporal interaction effects}

Using variance-based sensitivity analysis methods, an essential aspect is that the estimated $S_{i}^{\prime} s$ have interesting normalization properties. Indeed, from Eq. (5) normalized by $V(Y)$ and with Eq. (6), the sum of nicely scaled sensitivity measures between 0 and 1 can be written as

$$
1=\sum_{i} S_{i}+\sum_{i} \sum_{j} S_{i j}+\ldots+S_{1,2, \ldots, k} .
$$



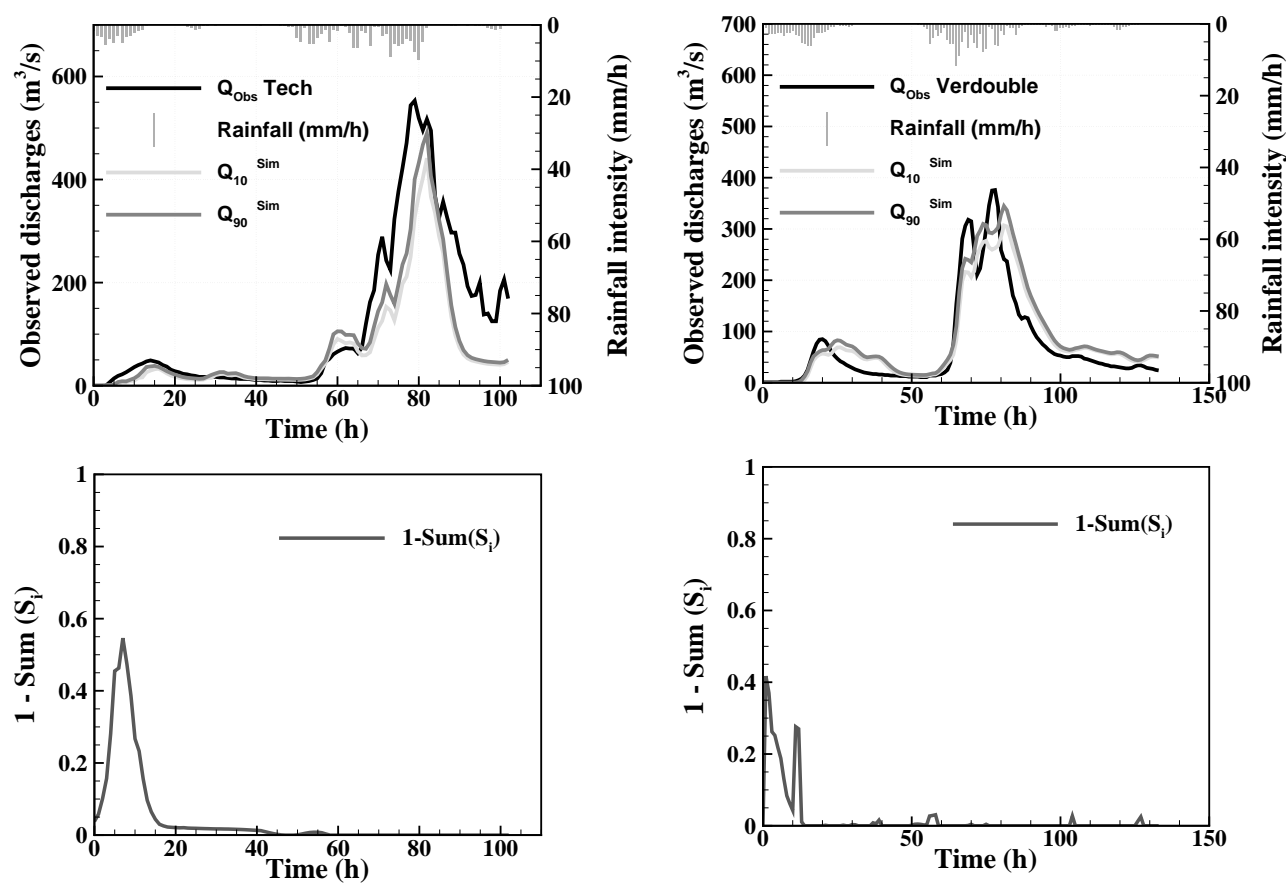

Fig. 11. (Top) Flash flood event of 15 March 2011 and $Q_{10}$ and $Q_{90}$ quintiles of simulated discharge for (left) the Tech at Pas-du-Loup and (right) the Verdouble at Tautavel. (Bottom) $1-\sum_{i} S_{i}$.
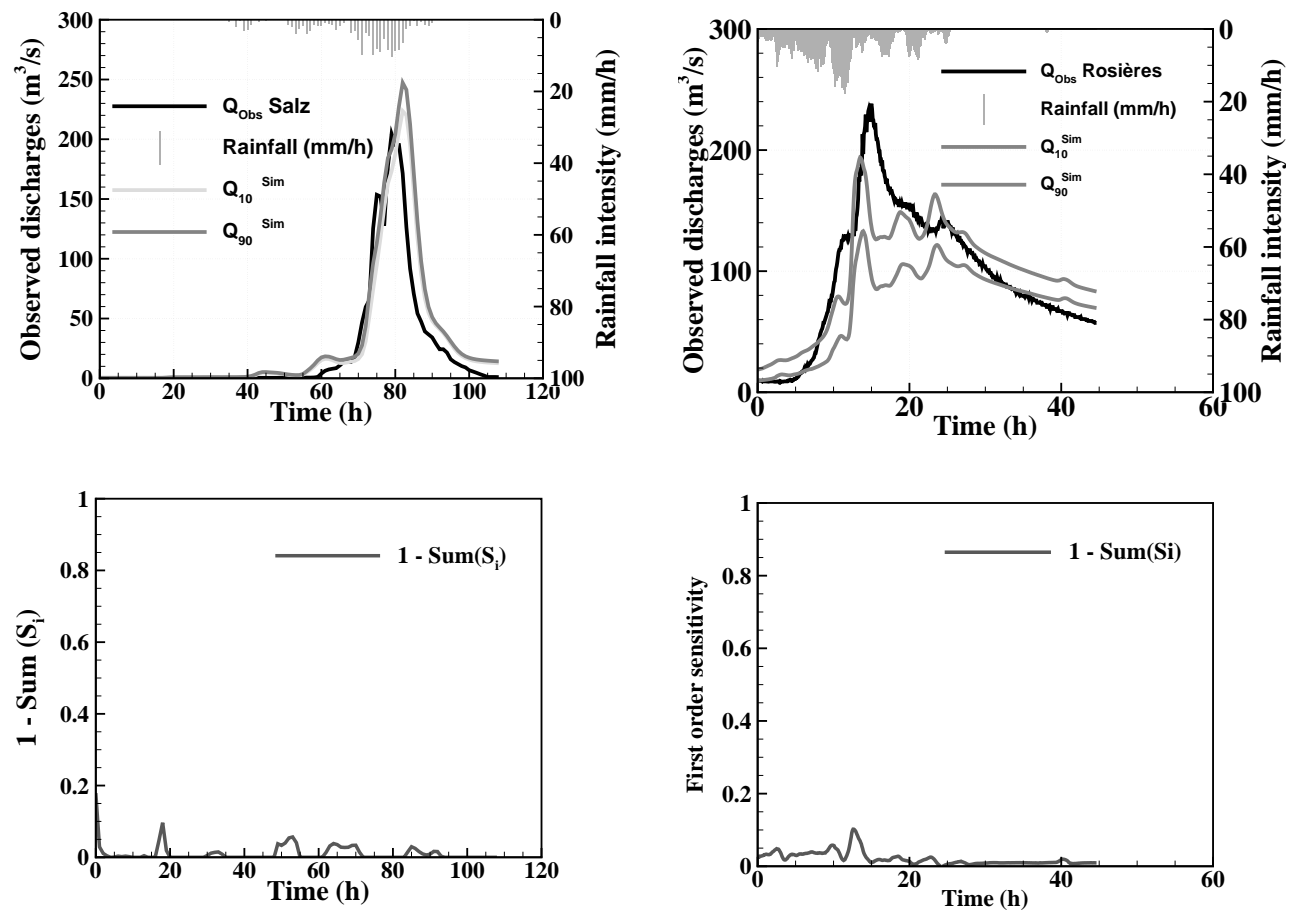

Fig. 12. (Top) $Q_{10}$ and $Q_{90}$ quintiles of simulated discharge on (left) 20 December 2000 for the Salz at Cassaignes and (right) 16 November 2006 for the Beaume at Rosières. (Bottom) $1-\sum_{i} S_{i}$. 
Given that the sum of all sensitivity indices (up to order $k$, with $k$ the number of input factors) sum up to 1 , it is possible to apprehend the importance of interactions using first-order sensitivity indices. By definition the difference $1-\sum_{i} S_{i}$ gives the sum of all higher order sensitivities and is therefore an indicator of the presence of interactions according to (Ratto et al., 2007a; Saltelli et al., 2000). Indeed the formulation of each summand of the HDMR (including second-order variances) is a conditional variance; that is to say the integral of the square of a real function (cf. Eq. 4), which implies the positivity of $V_{i j}$ 's and therefore $S_{i j}$ 's.

The difference $1-\sum_{i} S_{i}$ is presented for the validation events from Figs. 9 to 12. During hydrograph peaks, less than $10 \%$ of model outputs variance is explained by correlations between the five sensitive MARINE model parameters. Moreover, the highest correlation is at 0.6 after initialization (Fig. 9 at 1, 53 and 141 h; Fig. 10 at 5, 42, 53 and $77 \mathrm{~h}$; Fig. 11 (left) at $8 \mathrm{~h}$; and Fig. 11 (right) at $1 \mathrm{~h}$ ) or after first rainfall intensity peak (Fig. 10 at 12,53 and $84 \mathrm{~h}$; Fig. 11 (right) at $12 \mathrm{~h}$ ). These interactions reaching $60 \%$ of model variance when the model starts running or when it is first raining might be due to water partition among the model components, which can lead to parameter interactions. This indicates that water partitioning representation can be improved and begs questions about initialization data.

This low interacting behavior of MARINE model in general, with some differences in function of the catchmentflood type and magnitude, can be interpreted as an indicator of a correct process parameterization, especially during rising limbs. In summary, interactions play an important role at the initial stage of the rising limb (with peaks corresponding to the beginning of precipitation), and the model inputs influence tend to be more orthogonal (few interactions) when the flow is significant.

\section{Conclusions}

The aim of this contribution was to analyze hydrologic model sensitivity in the case of flash floods with a new approach in hydrological modeling - namely model output variance decomposition for temporal patterns of parameter sensitivity. Given a simple and parsimonious parameterization of MARINE model structure, TEDPAS are calculated on a significant number of contrasted validation flood events in the Cévennes and the Pyrenean region (France). Our results show the huge impact of soil depth on model sensitivity, which is consistent with recent case studies of the Cévennes (Braud et al., 2010; Roux et al., 2011). First-order sensitivity to the soil depth map multiplicative constant $C_{Z}$ explains more than $80 \%$ of model outputs variance when most hydrographs are peaking. Moreover, first-order sensitivity to subsurface lateral transmissivity constant $C_{\mathrm{KSS}}$ is responsible for $80 \%$ of model output variance for slow recessions or multi- ple peak hydrograph rises. Using models as learning tools with TEDPAS gives information on the different processes giving rise to the flood hydrograph in the following order: infiltrability, transfer and limitation by maximum soil storage capacity. Concerning the transfer function, successive sensitivity to drainage network's main channel and flood plain roughness likely depends on event dynamics and amplitude.

The small part of variance explained by correlations between MARINE parameters probably stems from model parsimony. First hours of simulations or rainfall intensity peaks are yet to be determined as the instant when correlation occurs, pointing to soil water content initialization or water distribution problems. Reduction of model uncertainty can be achieved by improving water partition between lateral flow components and other mechanisms such as exfiltration in the drainage network and its own representation. Measurements at different scales are still necessary to better constrain these flow dynamics. Moreover, in situ soil moisture measurements and smaller scale water balance modeling (Vincendon et al., 2010) would strengthen representation of soil saturation dynamics and increase simulation realism for catchment flash flood responses.

A general pattern of model response is found for Mediterranean flash flood events, but some peaks of sensitivity to infiltrability, subsurface during recession or friction coefficients, for example, can indicate particular process dynamics attributable to singular rainfall distributions. Combining variance-based sensitivity analysis in a regionalization framework along with spatial and temporal sensitivities derived from variational methods, following the intent of Castaings et al. (2009), could bring understanding in spatial temporal aggregation of flash-flood-generating processes and data/modeling uncertainties. The resonance between rainfall spatial and temporal distribution and catchment properties, in other words the catchment temporal dampening effect, could be accessible that way.

Ultimately it can be concluded that the variance-based temporal sensitivity analysis method presented here can be successfully applied to distributed hydrological models, allowing the following:

- analysis of the model processes temporal dynamics for each flood event,

- derivation of patterns of model responses according to the different characteristics of each event,

- emphasis of model structure or parameterization problems when an important part of the model variance is explained by correlations.

This method can be implemented with a very reasonable computational cost, and studies for other litho-pedological conditions, landscapes and climatic regions could bring insight, for example, to help the number of possible hydrological process representations to converge. 


\section{Appendix A}

Table A1. Notations.

\begin{tabular}{|c|c|c|}
\hline Notation & Unit & Meaning \\
\hline$a_{\mathrm{d}}$ & {$\left[m^{2}\right]$} & Drainage area \\
\hline$C_{K}$ & {$[-]$} & $\begin{array}{l}\text { Correction coefficient of the } \\
\text { saturated hydraulic conductivity }\end{array}$ \\
\hline$C_{Z}$ & {$[-]$} & $\begin{array}{l}\text { Correction coefficient of the soil } \\
\text { thickness }\end{array}$ \\
\hline$I$ & {$[\mathrm{~m}]$} & Cumulative infiltration \\
\hline$T_{0}$ & {$\left[\mathrm{~m}^{2} \mathrm{~s}^{-1}\right]$} & $\begin{array}{l}\text { Local transmissivity of fully } \\
\text { saturated soil }\end{array}$ \\
\hline$C_{\mathrm{KSS}}$ & {$[-]$} & $\begin{array}{l}\text { Correction coefficient of local trans- } \\
\text { missivity of fully saturated soil }\end{array}$ \\
\hline$M$ & {$[-]$} & Transmissivity decay parameter \\
\hline$H$ & [m] & Water depth \\
\hline$I$ & {$\left[\mathrm{~m} \mathrm{~s}^{-1}\right]$} & Infiltration rate \\
\hline$R$ & {$[\mathrm{~m}]$} & Rainfall rate \\
\hline$K$ & {$\left[\mathrm{~m} \mathrm{~s}^{-1}\right]$} & Saturated hydraulic conductivity \\
\hline$L_{\mathrm{NP}}$ & {$[-]$} & Performance criterion \\
\hline$K_{\mathrm{O}}$ & {$\left[\mathrm{m}^{-1 / 3} \mathrm{~s}^{-1}\right]$} & $\begin{array}{l}\text { Strickler roughness coefficient of } \\
\text { the overland }\end{array}$ \\
\hline$K_{\mathrm{D} 1}$ & {$\left[\mathrm{~m}^{-1 / 3} \mathrm{~s}^{-1}\right]$} & $\begin{array}{l}\text { Strickler coefficient of the main } \\
\text { channel (drainage network) }\end{array}$ \\
\hline$K_{\mathrm{D} 2}$ & {$\left[\mathrm{~m}^{-1 / 3} \mathrm{~s}^{-1}\right]$} & $\begin{array}{l}\text { Strickler coefficient of the hack } \\
\text { overbanks (drainage network) }\end{array}$ \\
\hline$Q$ & {$\left[\mathrm{~m}^{3} \mathrm{~s}^{-1}\right]$} & Discharge \\
\hline$S_{\mathrm{f}}$ & {$\left[\mathrm{m} \mathrm{m}^{-1}\right]$} & Friction slope \\
\hline$S_{0}$ & {$\left[\mathrm{~m} \mathrm{~m}^{-1}\right]$} & Bed slope \\
\hline$t_{\mathrm{p}}$ & {$[\mathrm{s}]$} & Time to ponding \\
\hline$U$ & {$\left[\mathrm{~m} \mathrm{~s}^{-1}\right]$} & Overland flow velocity \\
\hline$Z$ & {$[\mathrm{~m}]$} & Soil thickness \\
\hline$\theta_{i}$ & {$\left[\mathrm{~m}^{3} \mathrm{~m}^{-3}\right]$} & Initial water content of the soil \\
\hline$\theta_{s}$ & {$\left[\mathrm{~m}^{3} \mathrm{~m}^{-3}\right]$} & Saturated water content of the soil \\
\hline$\Psi$ & {$[\mathrm{m}]$} & Soil suction at wetting front \\
\hline
\end{tabular}

Acknowledgements. Financial support and data supply by the SCHAPI are gratefully acknowledged by the authors.

Edited by: S. Archfield

\section{References}

Albergel, C., de Rosnay, P., Gruhier, C., Munoz-Sabater, J., Hasenauer, S., Isaksen, L., Kerr, Y., and Wagner, W.: Evaluation of remotely sensed and modelled soil moisture products using global ground-based in situ observations, Remote Sens. Environ., 118, 215-226, 2012.

Andréassian, V., Perrin, C., Michel, C., Usart-Sanchez, I., and Lavabre, J.: Impact of imperfect rainfall knowledge on the efficiency and the parameters of watershed models, J. Hydrol., 250, 206-223, 2001.

Bessière, H.: Assimilation de données variationnelle pour la modélisation hydrologique distribuée des crues à cinétique rapide, $\mathrm{PhD}$ Thesis, 350 pp., Institut National Polytechnique de Toulouse, Toulouse, France, 2008.
Beven, K.: Changing ideas in hydrology - The case of physicallybased models, J. Hydrol., 105, 157-172, 1989.

Beven, K. J. and Binley, A. M.: The future of distributed models: model calibration and uncertainty prediction, Hydrol. Process., 6, 279-298, 1992.

Beven, K. J. and Kirkby, M. J.: A physically based, variable contributing area model of basin hydrology, Hydrol. Sci.-Bull., 24, 43-69, 1979.

Borga, M., Gaume, E., Creutin, J. D., and Marchi, L.: Surveying flash floods: gauging the ungauged extremes, Hydrol. Process., 22, 3883-3885, 2008

Braud, I., Roux, H., Anquetin, S., Maubourguet, M.-M., Manus, C., Viallet, P., and Dartus, D.: The use of distributed hydrological models for the Gard 2002 flash flood event: Analysis of associated hydrological processes, J. Hydrol., 394, 162-181, 2010.

Brocca, L., Tullo, T., Melone, F., Moramarco, T., and Morbidelli, R.: Catchment scale soil moisture spatial-temporal variability, J. Hydrol., 422-423, 63-75, 2012.

Castaings, W., Dartus, D., Le Dimet, F.-X., and Saulnier, G.-M.: Sensitivity analysis and parameter estimation for the distributed modeling of infiltration excess overland flow, Hydrol. Earth Syst. Sci. Discuss., 4, 363-405, doi:10.5194/hessd-4-363-2007, 2007.

Castaings, W., Dartus, D., Le Dimet, F.-X., and Saulnier, G.-M.: Sensitivity analysis and parameter estimation for distributed hydrological modeling: potential of variational methods, Hydrol. Earth Syst. Sci., 13, 503-517, doi:10.5194/hess-13-503-2009, 2009.

Crestaux, T., Le Maestre, O., and Martinez, J.-M.: Polynomial chaos expansion for sensitivity analysis, Reliability Engineering \&amp; System Safety, 94, 1161-1172, 2009.

Cukier, R. I., Fortuin, C. M., Shuler, K. E., Petschek, A. G., and Schaibly, J. H.: Study of the sensitivity of coupled reaction systems to uncertainties in rate coefficients. I Theory, J. Chem. Phys., 59, 3873-3878, 1973.

Davolio, S., Buzzi, A., and Malguzzi, P.: Orographic triggering of long lived convection in three dimensions, Meteorol. Atmos. Phys., 103, 35-44, 2009.

Delrieu, G., Ducrocq, V., Gaume, E., Nicol, J., Payrastre, O., Yates, E., Kirstetter, P.-E., Andrieu, H., Ayral, P.-A., Bouvier, C., Creutin, J.-D., Livet, M., Anquetin, S., Lang, M., Neppel, L., Obled, C., Parent-du-Châtelet, J., Saulnier, G.-M., Walpersdorf, A., and Wobrock, W.: The Catastrophic Flash-Flood Event of 8-9 September 2002 in the Gard Region, France: A First Case Study for the Cévennes-Vivarais Mediterranean Hydrometeorological Observatory, J. Hydrometeorol., 6, 34-52, 2005.

Efron, B. and Stein, C.: The Jackknife Estimate of Variance, Ann. Statist., 9, 586-596, 1981.

Fang, S., Gertner, G. Z., Shinkareva, S., Wang, G., and Anderson, A.: Improved generalized Fourier amplitude sensitivity test (FAST) for model assessment, Statist. Comput., 13, 221-226, 2003.

Freer, J., Beven, K. J., and Amboise, B.: Bayesian estimation of uncertainty in runoff prediction and the value of data: an application of the GLUE approach, Water Resour. Res., 32, 2161-2173, 1996.

Gaál, L., Szolgay, J., Kohnová, S., Parajka, J., Merz, R., Viglione, A., and Blöschl, G.: Flood timescales: Understanding the interplay of climate and catchment processes through comparative hydrology, Water Resour. Res., 48, W04511, 
doi:10.1029/2011WR011509, 2012.

Garambois, P. A., Larnier, K., Roux, H., Labat, D., and Dartus, D.: Characterization of catchment behaviour and rainfall selection for flash flood dedicated hydrologic model regionalization: catchments of the eastern Pyrenees, Hydrolog. Sci. J., in revision, 2012a.

Garambois, P. A., Larnier, K., Roux, H., Labat, D., and Dartus, D.: Analysis of radar rainfalls for flash flood dedicated hydrologic model regionalization: catchments of the eastern Pyrenees, Atmos. Res., in revision, 2012b.

Gatelli, D., Kucherenko, S., Ratto, M., and Tarantola, S.: Calculating first-order sensitivity measures: A benchmark of some recent methodologies, Reliability Engineering \&amp; System Safety, 94, 1212-1219, 2009.

Gaume, E., Bain, V., Bernardara, P., Newinger, O., Barbuc, M., Bateman, A., Blaskovicová, L., Blöschl, G., Borga, M., Dumitrescu, A., Daliakopoulos, I., Garcia, J., Irimescu, A., Kohnova, S., Koutroulis, A., Marchi, L., Matreata, S., Medina, V., Preciso, E., Sempere-Torres, D., Stancalie, G., Szolgay, J., Tsanis, I., Velasco, D., and Viglione, A.: A compilation of data on European flash floods, J. Hydrol., 367, 70-78, 2009.

Habets, F., Boone, A., Champeaux, J. L., Etchevers, P., Franchistéguy, L., Leblois, E., Ledoux, E., Le Moigne, P., Martin, E., Morel, S., Noilhan, J., Quintana Seguì, P., Rousset-Regimbeau, F., and Viennot, P.: The SAFRAN-ISBA-MODCOU hydrometeorological model applied over France, J. Geophys. Res., 113, 1984-2012, doi:10.1029/2007JD008548, 2008.

Hall, J. W., Tarantola, S., Bates, P. D., and Horritt, M. S.: Distributed Sensitivity Analysis of Flood Inundation Model Calibration, J. Hydr. Eng. ASCE, 131, 117-126, 2005.

Hornberger, G. M. and Spear, R. C.: An approach to the preliminary analysis of environmental systems, J. Environ. Manage., 12, 7$18,1981$.

Jing, Y.: Convergence and uncertainty analyses in Monte-Carlo based sensitivity analysis, Environmental Modelling \&amp; Software, 26, 444-457, 2011.

Kavetski, D., Kuczera, G., and Franks, S. W.: Bayesian analysis of input uncertainty in hydrological modeling: 1 . Theory, Water Resour. Res. 42, W03407, doi:10.1029/2005WR004368, 2006.

Kuczera, G. and Parent, E.: Monte Carlo assessment of parameter uncertainty in conceptual catchment models: the Metropolis algorithm, J. Hydrol., 211, 69-85, 1998.

Kuczera, G., Kavetski, D., Renard, B., and Thyer, M.: A limitedmemory acceleration strategy for mcmc sampling in hierarchical bayesian calibration of hydrological models, Water Resour. Res., 46, W07602, doi:10.1029/2009wr008985, 2010.

Li, Y., Kinzelbach, W., Zhou, J., Cheng, G. D., and Li, X.: Modelling irrigated maize with a combination of coupled-model simulation and uncertainty analysis, in the northwest of China, Hydrol. Earth Syst. Sci., 16, 1465-1480, doi:10.5194/hess-16-14652012, 2012.

Manus, C., Anquetin, S., Braud, I., Vandervaere, J.-P., Creutin, J.D., Viallet, P., and Gaume, E.: A modeling approach to assess the hydrological response of small mediterranean catchments to the variability of soil characteristics in a context of extreme events, Hydrol. Earth Syst. Sci., 13, 79-97, doi:10.5194/hess-1379-2009, 2009.

Mara, T. A.: Extension of the RBD-FAST method to the computation of global sensitivity indices, Reliability Engineering \&amp;
System Safety, 94, 1274-1281, 2009.

Massmann, C. and Holzmann, H.: Analysis of the behavior of a rainfall-runoff model using three global sensitivity analysis methods evaluated at different temporal scales, J. Hydrol., 475, 97-110, 2012.

Meselhe, E. A., Habib, E. H., Oche, O. C., and Gautam, S.: Sensitivity of Conceptual and Physically Based Hydrologic Models to Temporal and Spatial Rainfall Sampling, J. Hydrol. Eng., 14, 711-720, 2009.

Moussa, R., Chahinian, N., and Bocquillon, C.: Distributed hydrological modelling of a Mediterranean mountainous catchment Model construction and multi-site validation, J. Hydrol., 337, 35-51, 2007.

Nossent, J., Elsen, P., and Bauwens, W.: Sobol' sensitivity analysis of a complex environmental model, Environ. Modell. Softw., 26, 1515-1525, 2011.

Nuissier, O., Ducrocq, V., Ricard, D., Lebeaupin, C., and Anquetin, S.: A numerical study of three catastrophic precipitating events over southern France. I: Numerical framework and synoptic ingredients, Q. J. Roy. Meteorol. Soc., 134, 111-130, 2008.

Oakley, J. E. and O'Hagan, A.: Probabilistic sensitivity analysis of complex models: a Bayesian approach, J. Roy. Stat. Soc. B, 66, 751-769, 2004.

Oudin, L., Perrin, C., Mathevet, T., Andréassian, V., and Michel, C.: Impact of biased and randomly corrupted inputs on the efficiency and the parameters of watershed models, J. Hydrol., 320, 62-83, 2006.

Pappenberger, F., Frodsham, K., Beven, K., Romanowicz, R., and Matgen, P.: Fuzzy set approach to calibrating distributed flood inundation models using remote sensing observations, Hydrol. Earth Syst. Sci., 11, 739-752, doi:10.5194/hess-11-739-2007, 2007.

Pappenberger, F., Beven, K., J., Ratto, M., and Matgen, P.: Multimethod global sensitivity analysis of flood inundation models, Elsevier, Kidlington, ROYAUME-UNI, 14 pp., 2008.

Pilgrim, D. H., Chapman, T. G., and Doran, D. G.: Problems of rainfall-runoff modelling in arid and semiarid regions, Hydrolog. Sci. J., 33, 379-400, 1988.

Pushpalatha, R., Perrin, C., Le Moine, N., Mathevet, T., and Andréassian, V.: A downward structural sensitivity analysis of hydrological models to improve low-flow simulation, J. Hydrol., 411, 66-76, 2011

Ratto, M., Pagano, A., and Young, P.: State Dependent Parameter metamodelling and sensitivity analysis, Comput. Phys. Commun., 177, 863-876, 2007a.

Ratto, M., Young, P. C., Romanowicz, R., Pappenberger, F., Saltelli, A., and Pagano, A.: Uncertainty, sensitivity analysis and the role of data based mechanistic modeling in hydrology, Hydrol. Earth Syst. Sci., 11, 1249-1266, doi:10.5194/hess-11-12492007, 2007b.

Rawls, W. J., and Brakensiek, D. L.: Prediction of soil water properties for hydrologic modelling, Watershed management in the eighties: proceedings of the American Society of Civil ENgineers symposium, Denver, 30 April-1 May, 1985, ASCE, New York, 293-299, 1985.

Reusser, D. E. and Zehe, E.: Inferring model structural deficits by analyzing temporal dynamics of model performance and parameter sensitivity, Water Resour. Res., 47, W07550, doi:10.1029/2010WR009946, 2011. 
Reusser, D. E., Buytaert, W., and Zehe, E.: Temporal dynamics of model parameter sensitivity for computationnally expensive models with the Fourier amplitude sensitivity test, Water Resour. Res., 47, W07551, doi:10.1029/2010WR009947, 2011.

Robbez-Masson, J.-M., Mazzoni, C., Vallejo, S., Ernesty, D., and Falipou, P.: A regional multimedia soil and landscape database on the web in order to help use and teaching of soil data, 17th World congress of Soil Science, Bangkok, Thailand, 2002,

Roux, H., Labat, D., Garambois, P.-A., Maubourguet, M.-M., Chorda, J., and Dartus, D.: A physically-based parsimonious hydrological model for flash floods in Mediterranean catchments, Nat. Hazards Earth Syst. Sci., 11, 2567-2582, doi:10.5194/nhess-11-2567-2011, 2011.

Saltelli, A., Tarantola, S., and Chan, K. P.-S.: A Quantitative ModelIndependent Method for Global Sensitivity Analysis of Model Output, Technometrics, 41, 39-56, 1999.

Saltelli, A.: Making best use of model evaluations to compute sensitivity indices, Comput. Phys. Commun., 145, 280-297, 2002.

Saltelli, A. and Annoni, P.: How to avoid a perfunctory sensitivity analysis, Environ. Modell. Softw., 25, 1508-1517, 2010.

Saltelli, A. and Bolado, R.: An alternative way to compute Fourier amplitude sensitivity test (FAST), Comput. Stat. Data Anal., 26, 445-460, 1998.

Saltelli, A., Chan, K., and Scott, E. M.: Sensitivity analysis, Wiley, New York, 2000.

Saltelli, A., Tarantola, S., Campolongo, F., and Ratto, M.: Sensitivity analysis in practice: a guide to assessing Scientific models, John Wiley \& Son, Ltd., 2004.

Saltelli, A., Ratto, M., Tarantola, S., and Campolongo, F.: Sensitivity analysis practices: Strategies for model-based inference, Reliabil. Eng. Syst. Saf., 91, 1109-1125, 2006.

Saulnier, G.-M. and le Lay, M.: Sensitivity of flash-flood simulations on the volume, the intensity, and the localization of rainfall in the Cévennes-Vivarais region (France) Water Resour. Res., 45, W10425, doi:10.1029/2008WR006906, 2009.

Sieber, A. and Uhlenbrook, S.: Sensitivity analyses of a distributed catchment model to verify the model structure, J. Hydrol., 310, 216-235, 2005.

Smith, T. J. and Marshall, L. A.: Bayesian methods in hydrologic modeling: A study of recent advancements in Markov chain Monte Carlo techniques, Water Resour. Res., 44, W00B05, doi:10.1029/2008WR006906, 2008.

Sobol, I. M.: On sensitivity estimation for nonlinear mathematical models, Matematicheskoe Modelirovanie, 2, 112-118, 1990.

Sobol, I. M.: Sensitivity analysis for non-linear mathematical models, Math. Modell. Comput. Exp., (1), 407-414, 1993.

Sobol, I. M.: Global sensitivity indices for nonlinear mathematical models and their Monte Carlo estimates, Math. Comput. Simul., 55, 271-280, 2001.
Storlie, C. B. and Helton, J. C.: Multiple predictor smoothing methods for sensitivity analysis: Description of techniques, Reliabil. Eng. Syst. Saf., 93, 28-54, 2007.

Sudret, B.: Global sensitivity analysis using polynomial chaos expansions, Reliabil. En. Syst. Saf., 93, 964-979, 2008.

Tang, Y., Reed, P., Wagener, T., and van Werkhoven, K.: Comparing sensitivity analysis methods to advance lumped watershed model identification and evaluation, Hydrol. Earth Syst. Sci., 11, 793817, doi:10.5194/hess-11-793-2007, 2007a.

Tang, Y., Reed, P., van Werkhoven, K., and Wagener, T.: Advancing the identification and evaluation of distributed rainfall-runoff models using global sensitivity analysis, Water Resour. Res., 43, W06415, doi:10.1029/2006WR005813, 2007b.

Tarantola, S., Gatelli, D., and Mara, T. A.: Random balance designs for the estimation of first order global sensitivity indices, Reliabil. Eng. Syst. Saf., 91, 717-727, 2006.

Tarolli, P., Borga, M., Morin, E., and Delrieu, G.: Analysis of flash flood regimes in the North-Western and South-Eastern Mediterranean regions, Nat. Hazards Earth Syst. Sci., 12, 1255-1265, doi:10.5194/nhess-12-1255-2012, 2012.

van Griensven, A., Meixner, T., Grunwald, S., Bishop, T., Diluzio, M., and Srinivasan, R.: A global sensitivity analysis tool for the parameters of multi-variable catchment models, J. Hydrol., 324, 10-23, 2006.

Van Werkhoven, K., Wagener, T., Reed, P., and Tang, Y.: Characterization of watershed model behaviour across a hydroclimatic gradient, Water Resour. Res., 44, W01429, doi:10.1029/2007WR006271, 2008.

Vincendon, B., Ducrocq, V., Saulnier, G.-M., Bouilloud, L., Chancibault, K., Habets, F., and Noilhan, J.: Benefit of coupling the ISBA land surface model with a TOPMODEL hydrological model version dedicated to Mediterranean flash-floods, J. Hydrol., 394, 256-266, 2010.

Vrugt, J., ter Braak, C., Gupta, H., and Robinson, B.: Equifinality of formal (DREAM) and informal (GLUE) Bayesian approaches in hydrologic modeling?, Stoch. Environ. Res. Risk As., 23, 10111026, 2009.

Wagener, T., Boyle, D. P., Lees, M. J., Wheater, H. S., Gupta, H. V., and Sorooshian, S.: A framework for development and application of hydrological models, Hydrol. Earth Syst. Sci., 5, 13-26, doi:10.5194/hess-5-13-2001, 2001.

Wagener, T., McIntyre, N., Lees, M. J., Wheater, H. S., and Gupta, H. V.: Towards reduced uncertainty in conceptual rainfall-runoff modelling: dynamic identifiability analysis, Hydrolog. Process., 17, 455-476, 2003.

Xu, C.-Y., Tunemar, L., Chen, Y. D., and Singh, V. P.: Evaluation of seasonal and spatial variations of lumped water balance model sensitivity to precipitation data errors, J. Hydrol., 324, 80-93, 2006. 